\title{
Selective Deletion of Astroglial FMRP Dysregulates Glutamate Transporter GLT1 and Contributes to Fragile X Syndrome Phenotypes In Vivo
}

\author{
을 Haruki Higashimori, ${ }^{1}$ Christina S. Schin, ${ }^{1}$ Ming Sum R. Chiang, ${ }^{1}$ Lydie Morel, ${ }^{1}$ Temitope A. Shoneye, ${ }^{1}$ \\ David L. Nelson, ${ }^{2}$ and $\odot$ Yongjie Yang ${ }^{1,3}$ \\ ${ }^{1}$ Tufts University, Department of Neuroscience, Boston, Massachusetts 02111, 2Department of Molecular and Human Genetics, Jan and Dan Duncan \\ Neurological Research Institute, Baylor College of Medicine, Houston, Texas 77030, and ${ }^{3}$ Tufts University, Sackler School of Biomedical Sciences, Boston, \\ Massachusetts 02111
}

How the loss of fragile X mental retardation protein (FMRP) in different brain cell types, especially in non-neuron glial cells, induces fragile X syndrome (FXS) phenotypes has just begun to be understood. In the current study, we generated inducible astrocyte-specific Fmr1 conditional knock-out mice (i-astro-Fmr1-cKO) and restoration mice (i-astro-Fmr1-cON) to study the in vivo modulation of FXS synaptic phenotypes by astroglial FMRP. We found that functional expression of glutamate transporter GLT1 is $40 \%$ decreased in i-astro-Fmr1-cKO somatosensory cortical astrocytes in vivo, which can be fully rescued by the selective re-expression of FMRP in astrocytes in i-astro-Fmr1-cON mice. Although the selective loss of astroglial FMRP only modestly increases spine density and length in cortical pyramidal neurons, selective re-expression of FMRP in astrocytes significantly attenuates abnormal spine morphology in these neurons of i-astro-Fmr1-cON mice. Moreover, we found that basal protein synthesis levels and immunoreactivity of phosphorylated S6 ribosomal protein ( $\mathrm{p}$-s6P) is significantly increased in i-astro-Fmr1-cK0 mice, while the enhanced cortical protein synthesis observed in Fmr1 K0 mice is mitigated in i-astro-Fmr1-cON mice. Furthermore, ceftriaxone-mediated upregulation of surface GLT1 expression restores functional glutamate uptake and attenuates enhanced neuronal excitability in Fmr1 K0 mice. In particular, ceftriaxone significantly decreases the growth rate of abnormally accelerated body weight and completely corrects spine abnormality in Fmr1 K0 mice. Together, these results show that the selective loss of astroglial FMRP contributes to cortical synaptic deficits in FXS, presumably through dysregulated astroglial glutamate transporter GLT1 and impaired glutamate uptake. These results suggest the involvement of astrocytemediated mechanisms in the pathogenesis of FXS.

Key words: astrocyte; autism; FMRP; fragile X; glutamate transporter; protein synthesis

Significance Statement

Previous studies to understand how the loss of function of fragile X mental retardation protein (FMRP) causes fragile X syndrome (FXS) have largely focused on neurons; whether the selective loss of astroglial FMRP in vivo alters astrocyte functions and contributes to the pathogenesis of FXS remain essentially unknown. This has become a long-standing unanswered question in the fragile $\mathrm{X}$ field, which is also relevant to autism pathogenesis. Our current study generated astrocyte-specific Fmr 1 conditional knock-out and restoration mice, and provided compelling evidence that the selective loss of astroglial FMRP contributes to cortical synaptic deficits in FXS, likely through the dysregulated astroglial glutamate transporter GLT1 expression and impaired glutamate uptake. These results demonstrate previously undescribed astrocyte-mediated mechanisms in the pathogenesis of FXS.

\section{Introduction}

Fragile X syndrome (FXS) is caused by the loss of function of the fragile $\mathrm{X}$ mental retardation protein (FMRP), as a result of the

Received March 31, 2016; revised May 4, 2016; accepted May 22, 2016.

Author contributions: H.H. and Y.Y. designed research; H.H., C.S.S., M.S.R.C., L.M., and T.A.S. performed research; D.L.N. contributed unpublished reagents/analytic tools; H.H., C.S.S., M.S.R.C., and Y.Y. analyzed data; Y.Y. wrote the paper. abnormal expansion of CGG repeats (typically $>200$ repeats) in the promoter region of the FMR1 gene and its subsequent tran-

This work was supported by the National Institutes of Health (Grants R01-MH-099554 and R01-MH-106490 to Y.Y. and HD-083092 to D.L.N.), and by a joint postdoctoral fellowship from the Autism Science Foundation and the FRAXA Research Foundation (H.H.). We thank Dr. Mark Bear (Massachusetts Institute of Technology) and Dr. Emily Osterweil (University of Edinburg) for their help with the metabolic labeling procedure; Dr. Laura Liscum for help with the scintillation counter in the glutamate uptake assay; and the Tufts Center for Neuroscience Research for providing valuable core facilities. 
scriptional silencing. Among other functions, FMRP is a suppressor of protein synthesis in postsynaptic neuronal dendrites, acting through binding to mRNAs and stalling their translation on polyribosomes (Darnell et al., 2001; Bassell and Warren, 2008). FMRP-regulated mRNA substrates include synaptic proteins such as Arc, PSD95, and MAP1b (Bassell and Warren, 2008), implicating an important role for FMRP-mediated translational regulation in the development and maintenance of proper synaptic connectivity and signaling. In addition, recent studies (Deng et al., 2013) have characterized a translationindependent function of FMRP in regulating neurotransmitter release by directly binding to $\mathrm{BK}$ channel subunits in presynaptic neuronal terminals.

Loss of FMRP function in FXS patients has been modeled in Fmr1 knock-out (KO) mice, which recapitulate the majority of behavioral and synaptic phenotypes of FXS (Bakker CE et al., 1994; Comery et al., 1997; Kazdoba et al., 2014). Fmr1 KO mice have been extensively used in understanding FXS pathogenesis and testing of potential therapeutic interventions. However, how the loss of FMRP induces FXS phenotypes, especially the contribution of the loss of FMRP in different cell types in the CNS, has just begun to be understood. Selective deletion of FMRP in Purkinje neurons leads to enhanced long-term depression and deficits in eye-blink conditioning (Koekkoek et al., 2005). Complete deletion of FMRP in a large number $(60 \%)$ of cortical and hippocampal neurons, however, showed only activated AKT-mammalian target of rapamycin (mTOR) pathway signaling without apparent behavioral and synaptic phenotypes (Amiri et al., 2014). In addition, selective ablation of FMRP in adult neural stem cells leads to reduced hippocampal neurogenesis and disrupts hippocampus-dependent learning (Guo et al., 2011).

FMRP expression has been found in multiple CNS cell types, including astrocytes (Pacey and Doering, 2007; Higashimori et al., 2013). Whether and how the loss of in vivo astroglial FMRP contributes to the pathogenesis of FXS, however, remains essentially unknown. FMRP-deficient astrocytes are capable of inducing abnormal dendritic morphology of wild-type (WT) hippocampal neurons in cocultures (Jacobs and Doering, 2010). Subsequent studies found that Fmr1 KO astrocytes secrete excessive neurotrophin-3, which contributes to abnormal neuronal dendritic development (Yang et al., 2012). We have previously shown that expression of the major astroglial glutamate transporter glutamate type 1 transporter (GLT1) and glutamate uptake are significantly reduced in the cortex of Fmrl $\mathrm{KO}$ mice (Higashimori et al., 2013). In the current study, we generated inducible astrocyte-specific Fmrl conditional KO (i-astro-Fmr1$\mathrm{cKO}$ ) and restoration (i-astro-Fmr1-cON) mouse models and investigated the in vivo modulation of synaptic deficits by astroglial FMRP in these mouse models.

\section{Materials and Methods}

Animals. The Fmrl ${ }^{\text {f/f }}$ and Fmr1 ${ }^{\text {loxP-neo/loxP-neo }}$ mice were generated as previously described (Mientjes et al., 2006). BAC GLAST (glutamate/ aspartate transporter) CreERT transgenic mice (C57 BL6 background; stock \#012586) and Fmr1 KO mice (FVB background; stock \#003024) were obtained from The Jackson Laboratory. GLT1 ${ }^{+/-}$mice were a gift from Dr. Tanaka Kohichi (Tokyo Medical and Dental University, Tokyo, Japan). The Fmr1 ${ }^{\mathrm{f} / \mathrm{f}}$ and Fmr1 ${ }^{\text {loxP-neo/loxP-neo }}$ mice were bred with BAC

Correspondence should be addressed to Yongjie Yang, Tufts University, Department of Neuroscience, 136 Harrison Avenue, Boston, MA 02111. E-mail: yongjie.yang@tufts.edu.

DOI:10.1523/JNEUROSCI.1069-16.2016

Copyright $\odot 2016$ the authors $\quad 0270-6474 / 16 / 367080-16 \$ 15.00 / 0$
GLAST CreERT transgenic mice to generate inducible astrocyte-specific cKO and cON mice. We used only male mice from Fmrl KO, i-astroFmr1-cKO, i-astro-Fmr1-cON, and GLT1 ${ }^{+/-}$genotypes in all experiments, because the fmrl locus is on the $\mathrm{X}$ chromosome, and males are more severely affected than females among FXS patients and in mouse models. All mice were maintained on a $12 \mathrm{~h}$ light/dark cycle with food and water available ad libitum. Care and treatment of animals in all procedures strictly followed the National Institutes of Health Guide for the Care and Use of Laboratory Animals and the Guidelines for the Use of Animals in Neuroscience Research and the Tufts University institutional animal care and use committee.

Drug administration. Tamoxifen (4-OHT; Sigma-Aldrich) was resuspended at $20 \mathrm{mg} / \mathrm{ml}$ in ethanol and diluted in sunflower seed oil at a final concentration of $2 \mathrm{mg} / \mathrm{ml}$ in $10 \%$ ethanol. For astrocyte-specific Fmr1 $\mathrm{cKO}$ and cON mice, a daily intraperitoneal injection of $20 \mu \mathrm{l}$ of 4-OHT $(50 \mathrm{mg} / \mathrm{kg}$ ) were administered from postnatal day 4 (P4) to P9 for a total dose of $0.25 \mathrm{mg}$. All control mice received the same 4-OHT injections. For in vitro astrocyte cultures, cells were cultured in serum-free medium with $1 \mu \mathrm{m} 4-\mathrm{OHT}$ for $12 \mathrm{~h}$ and then switched to a regular serum complemented culture medium for $12 \mathrm{~h}$ (without 4-OHT), beginning on day 1 in vitro (DIV 1). The switch of culture medium was continued for another $3 \mathrm{~d}$ (DIV 4), then only regular astroglia culture medium was used until DIV 10 for collection. For ceftriaxone (Cef) injections, Fmrl KO mice receive saline $(0.9 \% \mathrm{NaCl})$ or ceftriaxone $(200 \mathrm{mg} / \mathrm{kg})$ from P7 to P28 through daily intraperitoneal injections. Primary astrocyte cultures. Cortices of $\mathrm{P} 0-\mathrm{P} 3$ mouse pups were used for astrocyte cultures, as previously described, without cAMP supplement (Higashimori et al., 2013). Cells were plated at a density of $1.0 \times 10^{6} \mathrm{cells} / \mathrm{ml}$ in six-well plates. The astrocyte medium is composed of DMEM supplemented with $10 \%$ fetal bovine serum (Sigma-Aldrich) and 1\% penicillin/streptomycin. Astrocytes become $90 \%$ confluent at $6-7 \mathrm{~d}$ in culture and were ready for experimentation.

Adeno-associated virus preparation and intracranial virus injection. The EF1 $\alpha$-DIO-eYFP adeno-associated virus (AAV) construct (catalog \#27056) was obtained from Addgene. EF1 $\alpha$-DIO-eYFP AAV was prepared from the University of North Carolina vector core. The pups (P1-P3) were anesthetized by placing them on ice for a few minutes. A mixture of AAV $(2 \mu \mathrm{l})$ and dye $(0.5 \mu \mathrm{l})$ was injected bilaterally in the cortex by piercing through the skull and skin with a thin glass pipette, as previously described (Broekman et al., 2006). Animals were placed on a warming pad following injection for recovery (active movement) before being returned to the cage.

Preparation of crude synaptosome membrane fractions and glutamate uptake assay. Glutamate uptake assay was performed with crude synaptosome preparation from mouse cortices using $0.32 \mathrm{~m}$ sucrose centrifugation method (Robinson et al., 1991). After total protein determination, $1 \mu \mathrm{Ci}$ of $\mathrm{L}-{ }^{3} \mathrm{H}$ glutamate and $100 \mu \mathrm{M}$ nonlabeled glutamate were mixed with $\mathrm{Na}^{+}$uptake buffer (total volume, $275 \mu \mathrm{l}$ ) and then added into $25 \mu \mathrm{l}$ of each synaptosome sample in 96-well multiscreen HTS Filter Plates (Millipore). After 6 min of incubation, uptake was terminated by putting the samples into an ice bath. Samples were then filtered using the Steriflip Vacuum Filtration System (Millipore) and washed $6 \times$ with ice-cold PBS while continually filtering the samples. Each filtered 96-well membrane was excised out and transferred for scintillation counting. Glutamate uptake from cultures was determined by adding $2 \mu \mathrm{Ci} \mathrm{L}-{ }^{3} \mathrm{H}$ glutamate (PerkinElmer) and $100 \mu \mathrm{M}$ nonlabeled glutamate into culture wells mixed with $\mathrm{Na}^{+}$uptake buffer (in mM: Tris 5, HEPES 10, $\mathrm{NaCl} 140$, $\mathrm{KCl} 2.5, \mathrm{CaCl}_{2} 1.2, \mathrm{MgCl}_{2} 1.2, \mathrm{~K}_{2} \mathrm{HPO}_{4} 1.2$, and glucose 10) in a total volume of $1 \mathrm{ml}$. After $6 \mathrm{~min}$ of incubation at $37^{\circ} \mathrm{C}$, uptake was terminated by putting the samples into an ice bath. Buffer was removed and reactions were washed twice with ice-cold HBSS (Life Technologies). An ice-cold $0.1 \mathrm{~N} \mathrm{NaOH}(0.5 \mathrm{ml})$ was used to lyse the cells. Aliquots of samples were transferred for scintillation counting (100 $\mu$ l of each in triplicate), and the total protein amount was determined by Bradford assay (Bio-Rad). Dihydrokainate (DHK; $500 \mu \mathrm{M}$ ) or DL-threo- $\beta$-benzyloxyaspartic acid (TBOA; $500 \mu \mathrm{M}$ ) was added into the appropriate wells in glutamate uptake assay. The number of disintegrations per minute was normalized by total protein concentration and converted to femtomoles per microgram per minute. 
Immunoblot and biotinylation. Anti-GLT1 (1:5000, rabbit) and antiGLAST (1:500, rabbit) antibodies were generous gifts from J.D. Rothstein (John Hopkins University, Baltimore, MD). Glutamate transporter immunoblots often show monomers $(62 \mathrm{kDa})$, dimers $(120 \mathrm{kDa})$, and sometimes multimers $(250 \mathrm{kDa})$, as previously described (Furuta et al., 1997). All monomers, dimers, and multimers (if present) were used for the quantification of transporter expression levels. Anti-FMRP monoclones 2F5 and 7G1 (1:1; Developmental Studies Hybridoma Bank, University of Iowa, Iowa City, IA), anti- $\beta$-actin (1:1000; Sigma-Aldrich), anti-GFAP (1:1000; Dako), and anti- $\beta$-III tubulin (1:1000; R\&D Systems) were purchased. Cerebral cortices from mice were homogenized. The total protein amount was determined by Bradford protein assay. A total of $10 \mu \mathrm{g}$ of cortical lysate or $50 \mu \mathrm{g}$ of total cell lysate were loaded on $4-15 \%$ gradient SDS-PAGE gels. Separated proteins were transferred onto a PVDF membrane (Bio-Rad) for $1 \mathrm{~h}$. The membrane was blocked with 3\% BSA in TBST (Tris buffer saline with $0.1 \%$ Tween 20) then incubated with the appropriate primary antibody overnight at $4^{\circ} \mathrm{C}$. On the following day, membrane was exposed to HRP-conjugated goat anti-rabbit secondary antibody (1:5000) diluted in TBST. Bands were visualized on CL-XPosureTM film (Thermo Scientific) by ECL Plus chemiluminescent substrate (Thermo Scientific). Different exposure times were used for detecting different proteins. For GLT1 surface biotinylation, cortical slices were prepared and transferred to a 12-well culture tray with $1 \mathrm{mg} / \mathrm{ml}$ EZ-Link Sulfo-NHS-SS-Biotin (Thermo Scientific) for $30 \mathrm{~min}$ at $4^{\circ} \mathrm{C}$ while being continuously oxygenated. Following three rinses to remove excess biotin, slices were lysed and lysates were incubated with streptavidin-conjugated magnetic beads (Thermo Scientific) for overnight at $4^{\circ} \mathrm{C}$. In following day, beads were washed three times with ice-cold salt buffer composed of the following (in $\mathrm{mm}$ ): 20 , Tris$\mathrm{HCl}, \mathrm{pH}$ 8.0, 150, NaCl, 1\% Triton X-100 5, EDTA, 10, NaF, 2 Na3Vo4, and 10 protease inhibitor. Bound substances were subject to SDS-PAGE, followed by immunoblotting with GLT1 antibodies.

Golgi staining and quantification of dendritic spines. Golgi staining was performed using the FD Rapid GolgiStain Kit (FD NeuroTechnologies), following the manufacturer instructions. Briefly, the brains were dissected and immersed in the impregnation solution for 2 weeks in the dark at room temperature (RT). Brains were then transferred into Solution C and stored at $4^{\circ} \mathrm{C}$ for $3 \mathrm{~d}$ in the dark. Brain sections $(200 \mu \mathrm{m})$ were then prepared using a cryostat, mounted, and dried at RT. Dried sections were processed following the manufacturer instructions. Images of dendrites of pyramidal neurons in layer $2 / 3$ of the somatosensory cortex (between 0.46 and $1.82 \mathrm{~mm}$ posterior to bregma) were acquired using a $60 \times \mathrm{ob}-$ jective with a Nikon A1R Confocal Microscope. Spines from secondary apical and basal dendrites were quantified from confocal image stacks. A dendritic region in focus was traced to measure its length using the ImageJ software. The number of spines in that region was then manually quantified by ImageJ and divided by the region length to obtain spine density. The spine length was manually traced and measured by ImageJ software.

Immunohistochemistry and confocal imaging. Animals were deeply anesthetized with ketamine $(100 \mathrm{mg} / \mathrm{kg})$ plus xylazine $(10 \mathrm{mg} / \mathrm{kg})$ in saline by intraperitoneal injection and perfused intracardially with $4 \%$ paraformaldehyde (PFA) in PBS. The brains were dissected and kept in $4 \%$ PFA overnight at $4^{\circ} \mathrm{C}$, then cryoprotected by immersion in $30 \%$ sucrose for $48 \mathrm{~h}$. Brains were embedded and frozen in Tissu-Tek OCT Compound (Sakura). Coronal sections $(20 \mu \mathrm{m})$ were prepared with a cryostat (model HM525, Leica) and mounted on glass SuperFrost + Slides (Fisher Scientific). Slides were rinsed three times in PBS, then treated with blocking buffer ( $1 \%$ BSA, $5 \%$ goat serum, and $0.2 \%$ Triton $\mathrm{X}-100$ in PBS) for $20 \mathrm{~min}$ at room temperature. Primary antibodies for FMRP (1:5; monoclonal antibody 2F5, Developmental Studies Hybridoma Bank), GFAP (1:1000; Calbiochem), NeuN (1:500; Millipore), Iba1 (1:500; Wako), Oligo2 (1:2000; Millipore), or phosphorylated s6 ribosomal protein (p-s6P; 1:350; Cell Signaling Technology) were incubated overnight at $4^{\circ} \mathrm{C}$ in blocking buffer. After washing slides three times in PBS, corresponding secondary antibody (1:2000; Jackson ImmunoResearch) was added for $90 \mathrm{~min}$ at room temperature. The sections were rinsed three times in PBS before mounting. Double immunostaining of $\mathrm{NeuN}$ and p-s6P was performed sequentially to avoid cross-reactivity of antibodies. For fluorescent reporter mouse sections, reporter signals were not amplified by antibody staining. Low-magnification images were taken using the Zeiss Axio Imager with ApoTome. Confocal images were taken using the A1R Confocal Laser-Scanning Microscope $(10-12 \mu \mathrm{m}$ $z$-stack with $0.5-1 \mu \mathrm{m}$ step) magnified with $40 \times$ (numerical aperture, 0.8 ) or $60 \times$ (numerical aperture, 1.0) objectives (Nikon Instruments).

Metabolic labeling. Brains of juvenile (P25-P30) male mice were dissected into the following ice-cold artificial CSF (aCSF) solution (in mM): $125 \mathrm{NaCl}, 3 \mathrm{KCl}, 1 \mathrm{MgCl}_{2}, 26 \mathrm{NaHCO}_{3}, 1.25 \mathrm{NaH}_{2} \mathrm{PO}_{4}, 10$ glucose, 1 $\mathrm{CaCl}_{2}$, and $400 \mu \mathrm{M} \mathrm{L}$-ascorbic acid, with osmolarity at 300-305 mOsm, and equilibrated with $95 \% \mathrm{O}_{2}-5 \% \mathrm{CO}_{2}$. Posterior parietal cortex slices $(500 \mu \mathrm{m})$ were prepared using a vibrotome (model VT1000, Leica Microsystems) and transferred into $32.5^{\circ} \mathrm{C}$ aCSF for $1 \mathrm{~h}$, followed by incubation at room temperature for $2.5-3 \mathrm{~h}$ to allow the recovery of protein synthesis. Slices were transferred to a chamber containing actinomycin $\mathrm{D}$ (ActD; $25 \mu \mathrm{M}$ ) for $30 \mathrm{~min}$ at $32.5^{\circ} \mathrm{C}$ to inhibit transcription. Slices were then incubated in $10 \mu \mathrm{Ci} / \mathrm{ml}{ }^{35} \mathrm{~S}$-Met/Cys for another $30 \mathrm{~min}$ at $32.5^{\circ} \mathrm{C}$ to measure protein synthesis. To verify that our measurements accurately reflect global protein synthesis, some of slices were coincubated with cycloheximide (CHX; $60 \mu \mathrm{M}$ ) and ActD for $30 \mathrm{~min}$. After labeling, slices were rapidly frozen in dry ice to stop ${ }^{35} \mathrm{~S}$-Met/Cys incorporation followed by homogenization in ice-cold homogenization buffer $(10 \mathrm{~mm}$ HEPES, pH 7.4, 2 mm EDTA, 2 mm EGTA, 1\% Triton X-100, and protease inhibitors [P-8340; Sigma-Aldrich], and incubated in 10\% trichloroacetic acid for $10 \mathrm{~min}$ on ice to precipitate radiolabeled proteins. Samples were then spun at $21,000 \times g$ for $10 \mathrm{~min}$, and the pellet was washed with ice-cold double-distilled $\mathrm{H}_{2} \mathrm{O}$ and resuspended in $1 \mathrm{~N}$ $\mathrm{NaOH}$ until dissolved. After adjustment to a neutral $\mathrm{pH}$ with $\mathrm{HCl}$, triplicate aliquots of each sample were added to a scintillation cocktail (HiSafe II, PerkinElmer) and read with a scintillation counter. Averaged triplicate counts per minute were divided by total protein concentrations to calculate the counts per minute per micrograms of protein. The values obtained each day were normalized to the ${ }^{35} \mathrm{~S}$-Met/Cys aCSF used for incubation and to determine the average incorporation of all slices analyzed in that experiment to control for daily variation in incorporation rate.

Brain slice preparation. Cortical brain slices were prepared from juvenile (P28-P40) male mice. Animals were anesthetized with a ketamine/ xylazine cocktail $(110 / 10 \mathrm{mg} / \mathrm{kg})$. The cortex was quickly removed and $300 \mu \mathrm{m}$ cortical slices were cut using a vibrotome (model VT1200, Leica Microsystems) in ice-cold aCSF with osmolarity at 300-305 mOsm, and equilibrated with $95 \% \mathrm{O}_{2}-5 \% \mathrm{CO}_{2}$. Slices were incubated at RT until needed.

Electrophysiology. Whole-cell patch-current recordings from pyramidal neurons in layer 5 somatosensory cortex were obtained by a Multiclamp 700B Amplifier filtered at $2 \mathrm{kHz}$ and sampled at $10 \mathrm{kHz}$ with a Digidata 1322A Digitizer (Molecular Devices). Patch pipettes made from thin-walled borosilicate glass (outer diameter, $1.5 \mathrm{~mm}$; internal diameter, $1.1 \mathrm{~mm}$; catalog \#BF150-110-7.5, Sutter Instrument) were pulled using a model P-97 Micropipette Puller (Sutter Instrument). Pipettes had resistances of $4-6 \mathrm{~m} \Omega$. pClamp version 9.2 (Molecular Devices) was used for data acquisition and storage. For whole-cell recording, the internal solution consisted of the following (in $\mathrm{mM}$ ): $\mathrm{K}^{+}$gluconate 130 , HEPES 10, EGTA 0.2, KCL 10, $\mathrm{Mg}_{2} \mathrm{Cl} 0.9, \mathrm{Mg}_{2}$ ATP 4, $\mathrm{Na}_{2}$ GTP 0.3, and phosphocreatine 20, $\mathrm{pH}$ adjusted to 7.2 with $\mathrm{KOH}$, and $290 \mathrm{mOsm}$. For the tight seal cell-attached patch recording, patch pipettes were filled with aCSF solution. Slices were continuously perfused with aCSF in a flow rate of $1-2 \mathrm{ml} / \mathrm{min}$ bubbled with $95 \% \mathrm{O}_{2}$ and $5 \% \mathrm{CO}_{2}$. Layer 5 pyramidal neurons were identified using a bright-field Nikon Eclipse e600FN Microscope with a $40 \times$ water-immersion lens (numerical aperture, 0.8 ) and infrared illumination. Baseline firing rates in different groups were adjusted to $1-1.5 \mathrm{~Hz}$ to compare the effect of DHK application on firing rate. Neuronal firing was continuously recorded for $\sim 15 \mathrm{~min}$. Recorded tight seal cell-attached layer 5 pyramidal neurons were located in the barrel hollows of the somatosensory cortex. For whole-cell recording, input resistance and capacitance were measured in a voltage clamp with a $500 \mathrm{~ms}, 5 \mathrm{mV}$ step pulse from a $-65 \mathrm{mV}$ holding potential. Cell capacitance was calculated by first obtaining the decay time constant of the transient current by the $5 \mathrm{mV}$ step pulse, then dividing this number by 
the series resistance. The threshold current was determined by a minimum $500 \mathrm{~ms}$ current step (20 pA step) required to evoke an action potential (AP) from resting membrane potential (RMP).

Data analysis. Electrophysiological recordings were analyzed using pClamp version 9.2 and Clampfit version 9.2 (Molecular Devices). All the resulting raw data were graphed and plotted in the GraphPad 5 program. Outliers were determined by the interquartile range outlier test in the Prism program for metabolic labeling experiments of Fmr $1 \mathrm{KO}$ and astrocyte-specific Fmr1 cKO cortical slices. One experiment (1-2 slices) was excluded from each group. All values are presented as the mean \pm SEM, with $n$ indicating the number of replicates. The corresponding statistical analysis is described in the legend of each figure. The sample size was determined by the power test for the appropriate statistical test used.

\section{Results}

\section{Generation of inducible astrocyte-specific Fmr1 cKO and} cON mice

Our and other previous studies (Pacey and Doering, 2007; Higashimori et al., 2013) have found that FMRP is expressed in astrocytes during development by FMRP immunostaining. To further characterize astroglial expression of FMRP at different developmental stages, we acutely isolated astrocytes from cortices of BAC ALDH1L1 eGFP mice in which astrocytes are selectively labeled with the eGFP reporter (Cahoy et al., 2008; Yang et al., 2011), by using fluorescence-activated cell sorting (FACS), as demonstrated in our previous studies (Yang et al., 2010, 2011). The expression of FMRP was clearly detected from lysates of acutely isolated cortical astrocytes $\left(1-1.6 \times 10^{6}\right.$ astrocytes, two mice per sample) by immunoblot at all tested time points (P30; Fig. 1A; P14 and P90 data not shown). The relative purity of astrocytes from the FACS was confirmed by the lack of $\beta$ IIItubulin expression in astrocytes sorted by FACS (Fig. 1A). To specifically investigate how astroglial FMRP may modulate neuronal deficits in FXS in vivo, we generated inducible astrocytespecific Fmrl cKO (deletion) and cON (restoration) mice by breeding $F m r 1^{\mathrm{f} / \mathrm{f}}$ (and $F m r 1^{\mathrm{f} /+}$ ) or $F m r 1^{\text {loxP-neo/loxP-neo }}$ with BAC GLAST CreERT transgenic mice (Fig. $1 B, C$ ). The $F m r 1^{\mathrm{f} / \mathrm{y}}$ mice show no difference in phenotype compared with WT mice, while Fmr $1^{\text {loxP-neo/y }}$ mice express very low levels $(8 \sim 10 \%)$ of FMRP and show phenotypes that are highly similar to those of Fmrl KO $\left(\mathrm{Fmr1}^{-/ y}\right)$ mice (Mientjes et al., 2006). FMRP levels can be restored in a Cre-dependent manner following deletion of the inserted neo gene from the fmrl allele in Fmr $1^{\text {loxP-neo/y }}$ mice. Although the glutamate transporter GLAST genomic promoter is also active in radial glia during early development (Regan et al., 2007), because we administered 4-OHT from P4 to P9, during which time radial glia in cortex all differentiated into astrocytes (Ge et al., 2012), we expected no GLAST-Cre-induced recombination in other CNS cell types in the cortex. To test the specificity and efficiency of GLAST CreERT-induced recombination in the cortex, we first bred BAC GLAST CreERT mice with Credependent Ail4 mice that express the floxed tdTomato (tdT) reporter (Madisen et al., 2010) and performed immunostaining with CNS cell type-specific markers NeuN, Olig2, Iba1, and GFAP. Indeed, the tdT reporter was selectively induced in astrocytes that are $\mathrm{GFAP}^{+}$, but had essentially no overlap with other CNS cell-type markers except 1-2\% Oligo2 immunoreactivity in the cortex (Fig. 1D). The GLAST genomic promoter is widely and selectively expressed in cortical astrocytes and is mostly active during postnatal development (Regan et al., 2007), thus is more efficient in inducing astrocyte-specific recombination, when 4-OHT is administered early postnatally, than conventional GFAP-CreER transgenic mice. We typically observed a large number of $\mathrm{tdT}^{+}$astrocytes in the cortex of GLAST CreERT $\times$ Ail $4^{\mathrm{f} / \mathrm{f}}$ mice (Fig. 1E). Subsequent calculations of $\mathrm{tdT}^{+}$astrocytes among total astrocytes (by subtracting other CNS cells from total $\mathrm{DAPI}^{+}$cells) show $>80 \%$ recombination efficiency.

We first examined FMRP expression levels in cultured astrocytes prepared from control $\left(\mathrm{CreERT}^{-} \mathrm{Fmrl}{ }^{\mathrm{f} / \mathrm{y}}\right.$ ) and astrocyte-specific cKO $\left(\mathrm{CreERT}^{+} \mathrm{Fmrl}^{\mathrm{f} / \mathrm{y}}\right)$ pups following 4-OHT treatment in culture medium. As shown in Figure $1 \mathrm{~F}$, FMRP levels were reduced $>80 \%$ in cultured cKO astrocytes, confirming its effective deletion in these astrocytes. Additionally, we bred BAC ALDH1L1 eGFP reporter mice with astrocytespecific $\mathrm{cKO}$ mice to label astrocytes and then acutely sorted cortical astrocytes from these mice. We found that the expression of FMRP in acutely isolated cortical astrocytes of astrocytespecific cKO mice is also significantly reduced (P30; Fig. 1G; quantification not shown), confirming that FMRP levels are indeed reduced in cortical astrocytes of astrocyte-specific cKO mice in vivo. Meanwhile, the deletion of the neo gene from the Fmr1 ${ }^{\text {loxP-neo/loxP-neo }}$ allele by GLAST-Cre recombinase significantly increases FMRP levels from 5\% of WT to 30\% of WT from the total cortical lysates in astrocyte Fmrl cON $\left(\right.$ CreERT $^{+}$ $\left.\mathrm{fmr} 1^{\text {loxP-neo/y }}\right)$ mice $(\mathrm{P} 40$; Fig. $1 \mathrm{H}, \mathrm{I})$. As we previously showed that astroglial FMRP mRNA is $15-20 \%$ of that in neurons using the translation ribosome affinity purification approach (Heiman et al., 2008), it is conceivable that the increased $25 \%$ of FMRP levels is a result of the selective re-expression of FMRP in cortical astrocytes.

To visualize specific Cre-dependent changes in FMRP expression of cortical astrocytes of astrocyte-specific cKO and cON mice in situ, we intracranially injected EF1 $\alpha$-DIO-eYFP AAV (Addgene) into astrocyte-specific cKO $\left(\mathrm{CreERT}^{+} \mathrm{Fmrl}^{\mathrm{f} / \mathrm{y}}\right)$ or cON $\left(\mathrm{CreERT}^{+} \mathrm{Fmrl}^{\text {loxP-neo/y }}\right)$ pups (P0-P2). The eYFP open reading frame (ORF) is inverted and double floxed on the EF1 $\alpha$ DIO-eYFP construct, and the eYFP expression can only be induced following Cre-dependent deletion of the loxP site and ORF inversion. Thus, the eYFP induction faithfully indicates the positive Cre-dependent deletion or restoration of FMRP in eYFP ${ }^{+}$ astrocytes, respectively. We also injected AAV-gfap-eGFP into control $\left(\mathrm{CreERT}^{-} \mathrm{Fmrl}^{\mathrm{f} / \mathrm{y}}\right.$ or CreERT $\left.{ }^{-} \mathrm{Fmrl}^{\text {loxP-neo/y }}\right)$ pups to label astrocytes, which facilitates the identification of FMRP immunostaining signals in astrocytes. We then performed FMRP immunostaining and found clear FMRP immunoreactivity in cortical astrocytes (Fig. 1Ja, white arrows) of control mice (P26); however, essentially no FMRP immunoreactivity was found in cortical astrocytes of astrocyte-specific cKO mice (Fig. $1 \mathrm{Jb}$ ). Conversely, we found clear FMRP immunoreactivity in cortical astrocytes of astrocyte-specific $\mathrm{cON}$ mice (P40; Fig. $1 \mathrm{~Kb}$, white arrows) but minimal FMRP immunoreactivity in cortical astrocytes of control $\left(\right.$ CreERT $^{-}$Fmr $\left.^{\text {loxP-neo/y }}\right)$ mice (Fig. $\left.1 \mathrm{Ka}\right)$. In addition, we found that the FMRP immunoreactivity in cortical neurons was unaltered in astrocyte-specific cKO mice and was not induced in astrocyte-specific cON mice (data not shown). The expression of Cre or the insertion of loxP alone has no effect on FMRP expression (data not shown), thus $\mathrm{CreERT}^{+} \mathrm{Fmrl}^{+/ \mathrm{y}}$ genotype mice were also used as controls in some of the following experiments. Together, these results demonstrate that FMRP is selectively deleted or re-expressed in cortical astrocytes in astrocyte-specific $\mathrm{cKO}$ or $\mathrm{CON}$ mice, respectively. These newly generated FXS mouse models are therefore valuable tools for specifically investigating in vivo roles of astroglial FMRP in altering astrocyte functions and modulating neuronal deficits in FXS. 


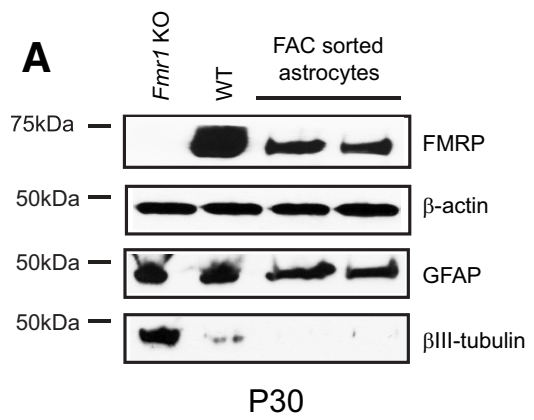

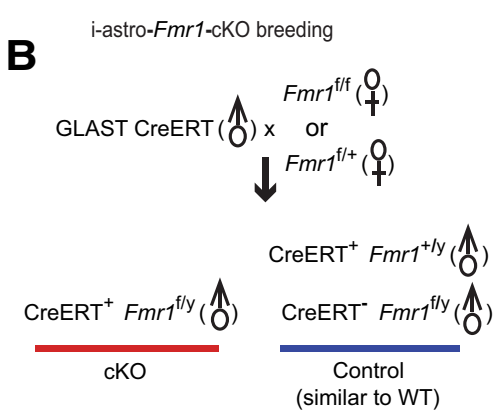

C i-astro-Fmr1-cON breeding

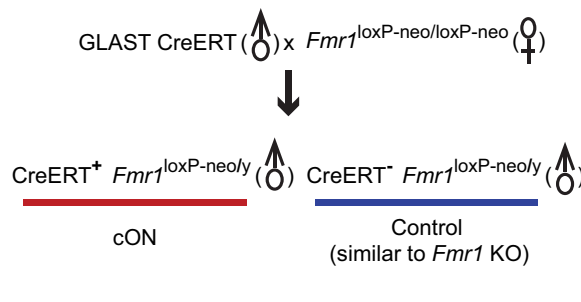

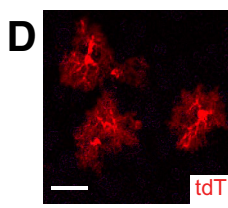
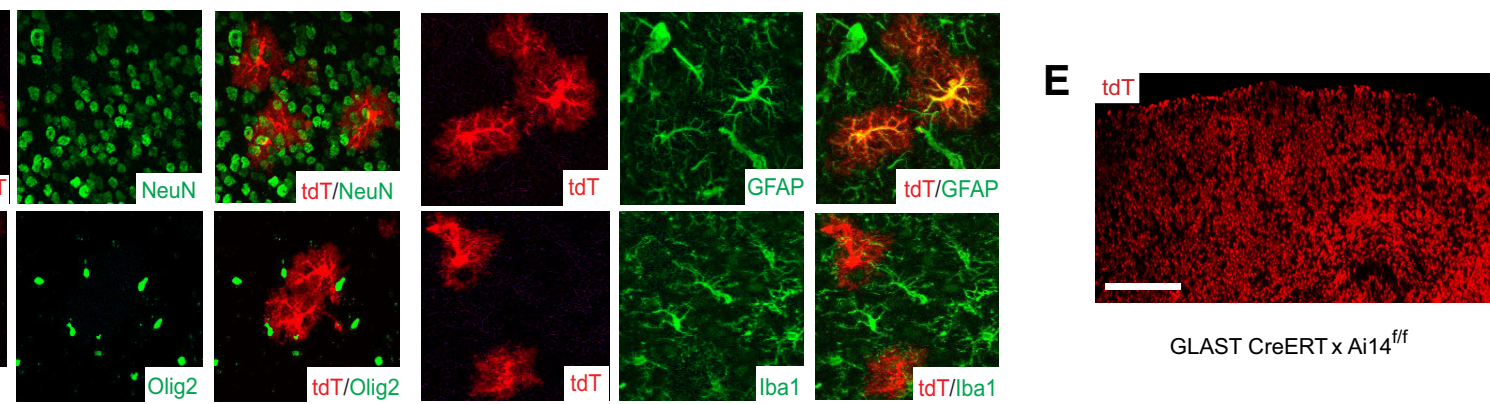

GLAST CreERT $\times$ Ai $14^{\mathrm{f} / \mathrm{f}}$
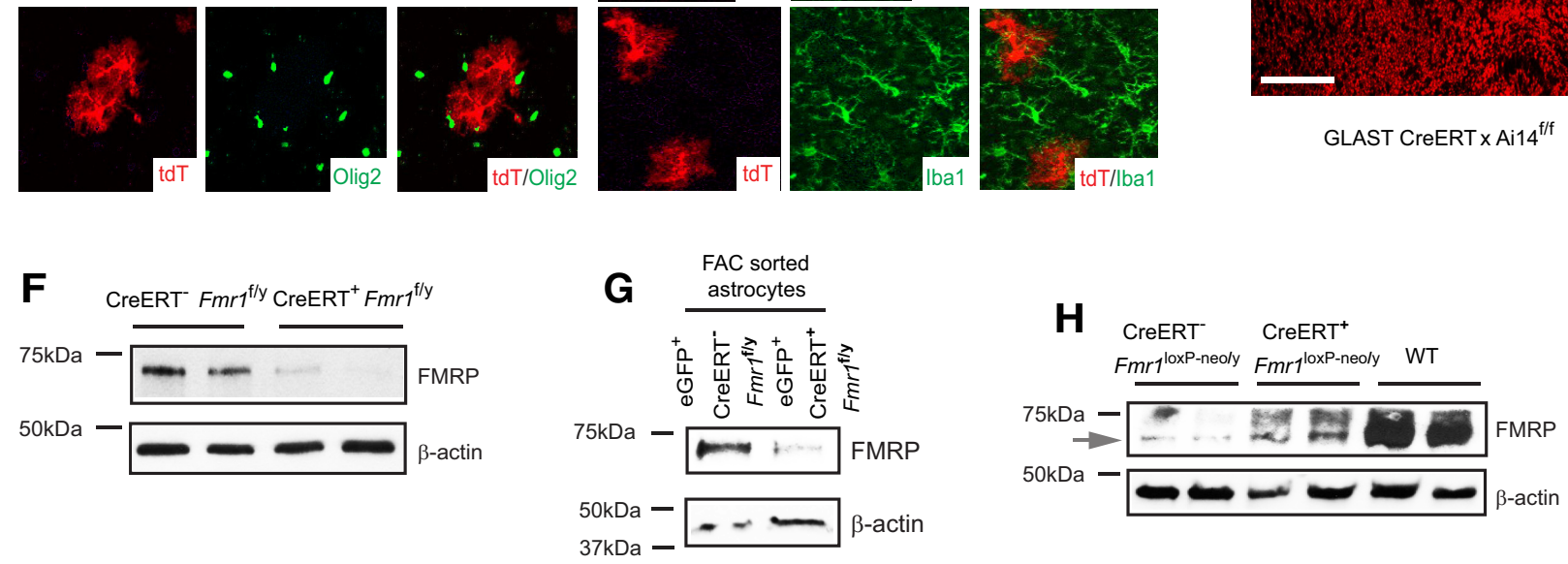

$\mathbf{J}$
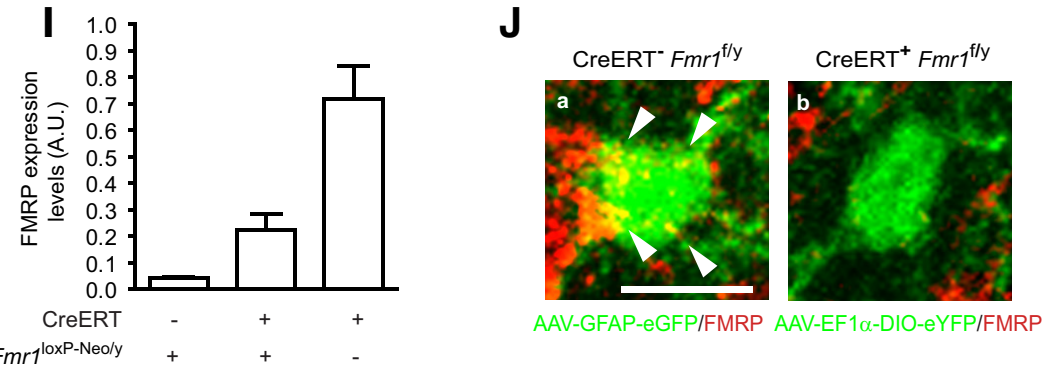

K

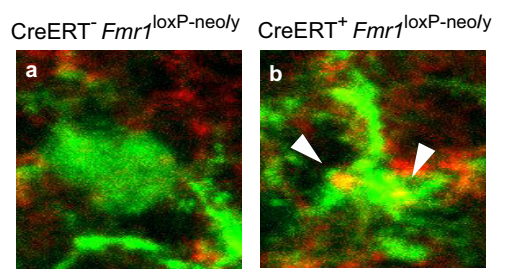

AAV-GFAP-eGFP/FMRP AAV-EF1 $\alpha$-DIO-eYFP/FMRP

Figure 1. Generation of inducible astrocyte-specific Fmr1 conditional KO (i-astro-Fmr1-cKO) and restoration (i-astro-Fmr1-CON) mice. A, A representative immunoblot of FMRP from acutely isolated (through FACS) cortical astrocytes (P30). B, C, Breeding diagrams for generating i-astro-Fmr1-cKO (B) and i-astro-Fmr1-CON (C) mice. $\boldsymbol{D}$, Representative immunostaining images of CNS cell type-specific makers on CreERT ${ }^{+}$Ai14 mice. Scale bar, $25 \mu \mathrm{m}$. $\boldsymbol{E}$, Representative tdT reporter expression in cortical astrocytes of GLAST CreERT ${ }^{+}$Ai14 mice. Scale bar, 2 mm. $\boldsymbol{F}$, A representative immunoblot of FMRP expression from cultured astrocytes derived from control and astrocyte-specific cKO mice following 4-0HT treatment; $n=4$ mice/group. $\mathbf{G}$, A representative immunoblot of

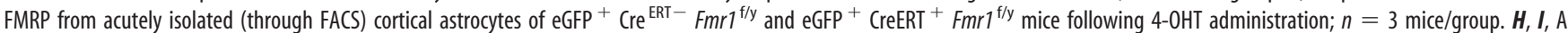
representative immunoblot $(\boldsymbol{H})$ and quantification $(\boldsymbol{I})$ of FMRP from cortical tissues of astrocyte-specific $\mathrm{CON}$ and control mice following 4-OHT administration. The gray arrow indicates the correct FMRP immunoreactivity band; $n=7$ mice/group. $\boldsymbol{J}, \boldsymbol{K}$, Immunostaining of FMRP in cortical sections from astrocyte-specific cKO $(\boldsymbol{J})$ or $\mathrm{CON}(\boldsymbol{K})$ mice following 4-0HT administration. White arrows indicate the FMRP immunoreactivity in eGFP ${ }^{+}$or eYFP $^{+}$astrocytes. Scale bar, $100 \mu \mathrm{m}$.

Selective loss of astroglial FMRP dysregulates glutamate transporter GLT1, impairs extracellular glutamate uptake, and enhances neuronal excitability in the cortex of astrocyte-specific cKO mice

We previously demonstrated that GLT1 (but not GLAST or EAAC1) expression levels and functional glutamate uptake are significantly reduced (40-50\%) in the cortex of Fmrl KO mice (at least until the age of P120; Higashimori et al., 2013). To determine whether GLT1 dysregulation results from the selective loss of astroglial FMRP in vivo, we here examined GLT1 expression and glutamate uptake in the cortex of astrocyte-specific $\mathrm{cKO}$ mice. Our GLT1 immunoblot results showed that GLT1 protein levels were decreased by $40 \%$ (Fig. $2 A, B ; p=0.001$ ). The total and GLT1-mediated glutamate uptake were also decreased by $>50 \%(p<0.0006$ and $p<0.002$, respectively) in the cortex of astrocyte-specific cKO $\left(\mathrm{CreERT}^{+} \mathrm{Fmrl}^{\mathrm{f} / \mathrm{y}}\right)$ mice when compared with those of control $\left(\mathrm{CreERT}^{-} \mathrm{Fmrl}^{\mathrm{f} / \mathrm{y}}\right.$ or $\mathrm{CreERT}^{+} \mathrm{Fmrl}^{+/ \mathrm{y}}$ ) cortices at P40 (Fig. 2C,D). However, the expression of another 
A

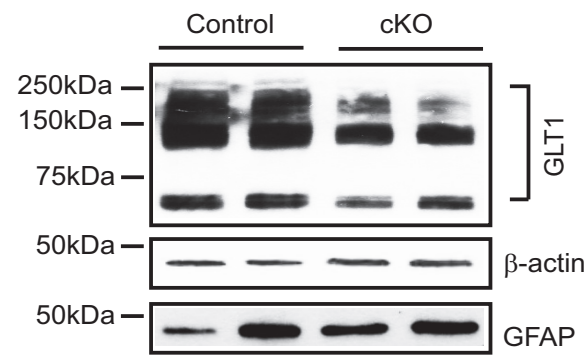

B

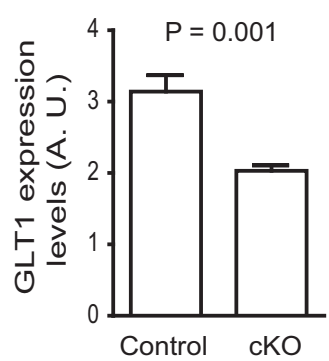

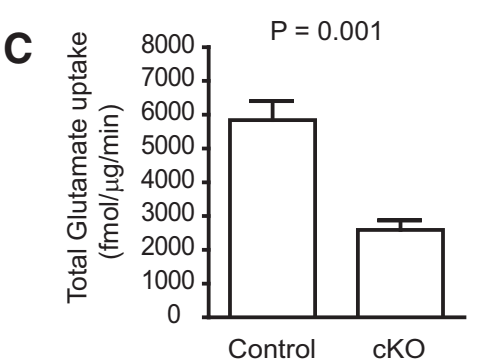

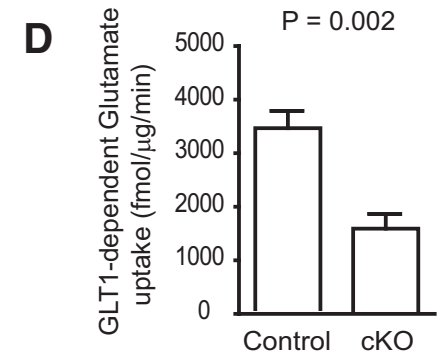

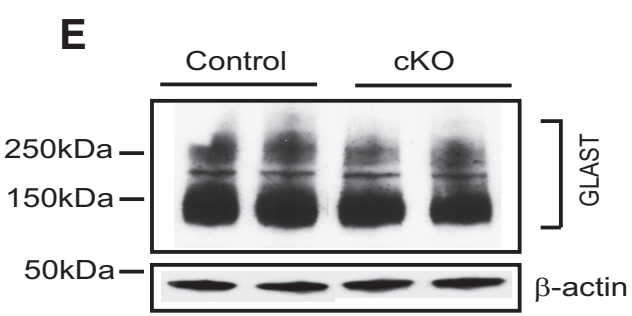

$\mathbf{F}$

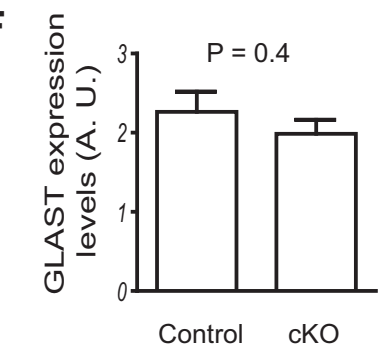

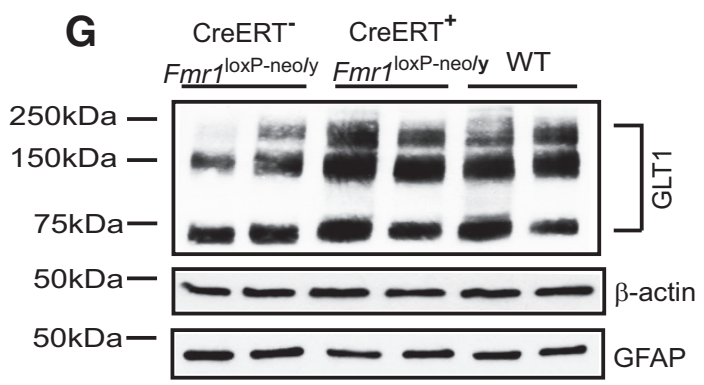

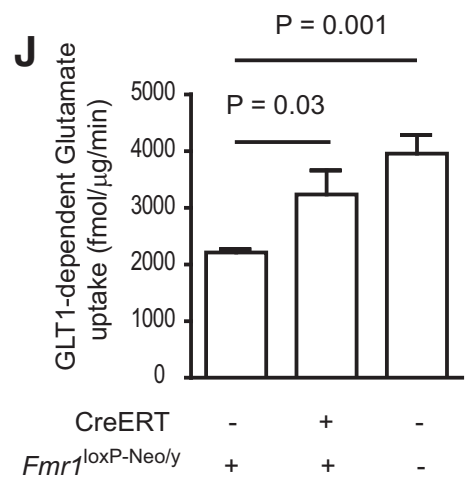

H

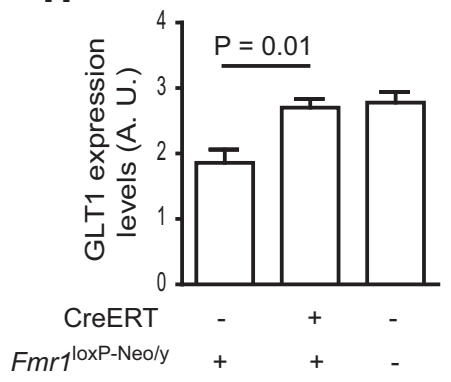

I

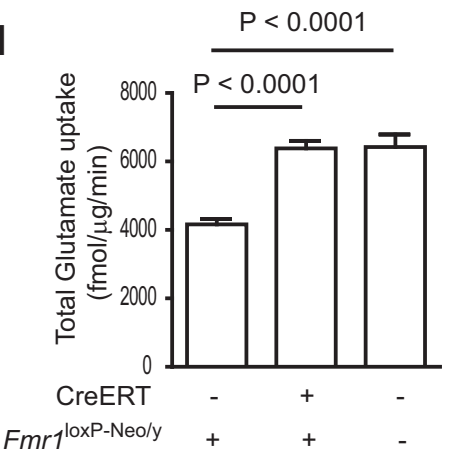

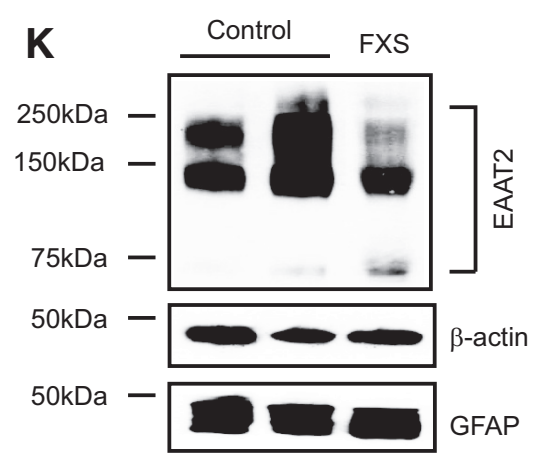

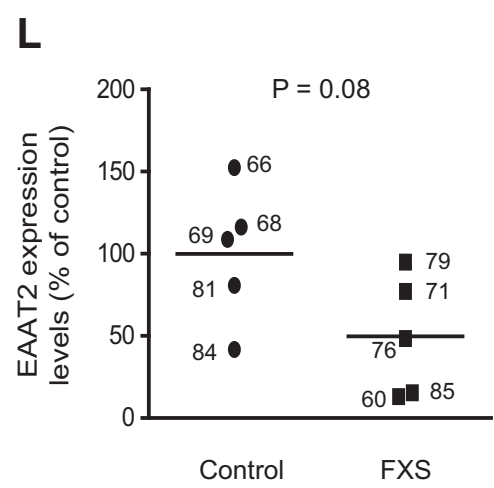

Figure 2. Astroglial FMRP regulates functional expression of GLT1 in vivo. $A, B, A$ representative immunoblot of GLT1 $(\boldsymbol{A})$ and its quantification $(\boldsymbol{B})$ from cortex of astrocyte-specific cK0 and control mice (P40). $n=6-7$ mice/group. $\boldsymbol{C}, \boldsymbol{D}$, Total (C) and GLT1-mediated (D) functional glutamate uptake in the cortex of astrocyte-specific cKO and control mice; $n=6-8$ mice/group. $\boldsymbol{E}, \boldsymbol{F}, \mathrm{A}$ representative immunoblot of GLAST $(\boldsymbol{E})$ and its quantification $(\boldsymbol{F})$ from the cortex of astrocyte-specific cKO and control mice (P40); $\boldsymbol{n}=5$ mice/group. $\boldsymbol{G}, \boldsymbol{H}$, A representative immunoblot of GLT1 (G) and its quantification $(\boldsymbol{H})$ from the cortex of astrocyte-specific CON (CreERT $\left.{ }^{+} F m r 1^{\text {loxP-neo/y }}\right)$, control (Cre ${ }^{\text {ERT }-}$ Fmr $\left.1^{\text {loxP-neo/y }}\right)$, and WT mice (P40); $n=5$ mice/group. $\boldsymbol{I}, \boldsymbol{J}$, Total $(\boldsymbol{I})$ and GLT1-mediated (J) functional glutamate uptake in the cortex of astrocyte-specific cON (CreERT $\left.{ }^{+} F m r 1^{\text {loxP-neo/y }}\right)$, control (Cre ${ }^{\text {ERT- }} F m r 1^{\text {loxP-neo/y) }}$, and WT mice; $n=5$ mice/group. DHK, $500 \mu$ M; TBOA, $500 \mu \mathrm{M} . \boldsymbol{K}, \boldsymbol{L}$, A representative immunoblot of human glutamate transporter EAAT2 $(\boldsymbol{K})$ and its quantification $(\boldsymbol{L})$ from human FXS and age-matched control postmortem cortical tissues; $n=$ 5 patients/group. The age of each tissue sample is labeled next to the data point. The $p$ values were determined using the Student's $t$ test or one-way ANOVA with post hoc Bonferroni's test.

astroglial glutamate transporter GLAST was not altered in astrocyte-specific cKO mice when compared with control mice (Fig. 2E,F). The GLT1 reduction in astrocyte-specific cKO mice is highly similar to our previously observed GLT1 reduction (45\%) in full Fmrl KO mice (Higashimori et al., 2013). Interest- ingly, reduced GLT1 protein expression and impaired total/ GLT1-specific glutamate uptake was also observed in control $\left(\right.$ CreERT $^{-}$Fmrl $^{\text {loxP-neo/y }}$ ) mice in which FMRP levels are $\sim 5 \%$ of WT levels (Fig. 2G-J), further demonstrating that GLT1 functions are dysregulated in response to reduced FMRP levels. The 
Table 1. Basic electrophysiological properties of cortical pyramidal neurons

\begin{tabular}{|c|c|c|c|c|c|}
\hline & $\mathrm{RMP}(\mathrm{mV})$ & Input resistance $(\mathrm{m} \Omega$ ) & Capacitance (pF) & AP threshold (mV) & AP spike height (mV) \\
\hline$F m r 1^{+/ y}$ & $-66.38 \pm 2$ & $136.5 \pm 20.1$ & $72 \pm 6.8$ & $-34 \pm 1.6$ & $80.1 \pm 6.2$ \\
\hline$F m r 1^{-/ y}$ & $-64.68 \pm 2.1$ & $139.2 \pm 19.1$ & $70.5 \pm 4.5$ & $-34.2 \pm 1.9$ & $74.6 \pm 6.7$ \\
\hline $\mathrm{CreERT}^{-} \mathrm{Fmr}^{\mathrm{f} / \mathrm{y}}$ & $-66 \pm 1.6$ & $135.7 \pm 12$ & $70.5 \pm 3.5$ & $-34.4 \pm 1.7$ & $81.4 \pm 8.2$ \\
\hline $\mathrm{CreERT}^{+} \mathrm{Fmr}^{\mathrm{f} / \mathrm{y}}$ & $-66 \pm 1.8$ & $141.1 \pm 32$ & $68.7 \pm 4.3$ & $-33.9 \pm 1.7$ & $76.6 \pm 7.1$ \\
\hline CreERT $^{-}$Fmr $^{\text {loxP-Neo/y }}$ & $-64.9 \pm 1.7$ & $151.9 \pm 15.6$ & $66.4 \pm 6.8$ & $-35.3 \pm 1.7$ & $76 \pm 6.7$ \\
\hline $\mathrm{CreERT}^{+} \mathrm{Fmr}{ }^{\text {loxP-Neo/y }}$ & $-65.5 \pm 1.4$ & $136.6 \pm 10.2^{*}$ & $69.9 \pm 2.8$ & $-33.8 \pm 1.7^{*}$ & $79 \pm 8.4$ \\
\hline
\end{tabular}

Values are reported as the mean \pm SEM.

${ }^{*} p<0.05$ when compared with CreERT ${ }^{-}{ }^{F m r}{ }^{\text {loxP-Neo/y }} ; n=12-14$ cells/group.

selective re-expression of FMRP in astrocytes in astrocytespecific cON $\left(\mathrm{CreERT}^{+} \mathrm{Fmrl}^{\text {loxP-neo/y }}\right.$ ) mice, however, fully restores the reduced GLT1 protein expression and total/GLT1specific glutamate uptake observed in control (CreERT $^{-}$ Fmr1 ${ }^{\text {loxP-Neo/y }}$ ) mice to WT levels (Fig. $2 G-J$ ), confirming the specific effects of the loss of astroglial FMRP on functional GLT1 reduction. Expression of Cre or insertion of loxP alone has no effect on GLT1 expression (data not shown). These results indicate that astroglial FMRP significantly regulates functional GLT1 expression in vivo, and that the absence of astroglial FMRP alone plays a primary and direct role in the functional reduction of GLT1 observed in Fmr1 KO mice.

The expression of human excitatory amino acid transporter 2 (EAAT2), the analog of rodent GLT1, in postmortem FXS brain tissues remains unexplored. We thus examined EAAT2 expression levels in human FXS and age-matched control cortical tissues (obtained from the National Institute of Child Health and Human Development Brain and Tissue Bank for Developmental Disorders) and found a clear trend of reduced EAAT2 protein levels in FXS samples when compared with age-matched controls (Fig. $2 K$ ), though they were not statistically significant (Fig. $2 L$; $p=0.08$ ), likely due to the wide age range of individuals and the limited number of samples. These results suggest that EAAT2 expression is also dysregulated, at least in a subset of human FXS patients.

To determine whether reduced (40\%) GLT1 expression and impaired glutamate uptake affects neuronal excitability, we performed whole-cell recording and cell-attached voltage-clamp recordings on layer 5 somatosensory pyramidal neurons on cortical slices of astrocyte-specific cKO mice (P28-P40). We first measured basic membrane properties of these neurons. The RMP (control, $-66 \pm 1.6 \mathrm{mV}$; cKO, $-66 \pm 1.8 \mathrm{mV}$ ) and input resistance (control, $135.7 \pm 12 \mathrm{~m} \Omega$; cKO, $141.1 \pm 32 \mathrm{~m} \Omega$ ) were not significantly different between control and astrocyte-specific cKO mice. Neither were there any significant differences in capacitance, AP threshold, and AP spike height (Table 1). Similarly, no significant differences in these basic electrophysiological parameters of layer 5 pyramidal neurons were found between Fmr1 $\mathrm{KO}$ and WT mice (Table 1), which is consistent with previous reports (Meredith et al., 2007). We next applied 10-50 $\mu \mathrm{M}$ DHK, a selective GLT1 antagonist, to gradually block GLT1 activity and then measured neuronal firing rate. DHK in the 10-50 $\mu \mathrm{M}$ range only partially blocks GLT1 activity, thus slightly elevating extracellular glutamate levels and potentiating neuronal activation. This measurement helps differentiate neuronal responses to a slightly elevated extracellular glutamate environment between control and astrocyte-specific cKO mice. Bath application of 10 $\mu \mathrm{M}$ DHK in astrocyte-specific cKO cortical slices resulted in a $45 \%(p<0.001)$ increase (Fig. $3 A, B)$ in firing rate compared with that in $10 \mu \mathrm{m}$ DHK-treated control slices, suggesting that pyramidal neurons in astrocyte-specific cKO slices are more sen- sitive to slightly elevated extracellular glutamate levels (induced by the $10 \mu \mathrm{M}$ DHK application). The application of $50 \mu \mathrm{M}$ DHK, however, similarly increases the firing rate of pyramidal neurons in both control and astrocyte-specific cKO slices (Fig. 3B), indicating a similarly significant blockade of GLT1 in both control and astrocyte-specific cKO slices. These results suggest that cortical pyramidal neurons from astrocyte-specific cKO mice could be more sensitive to slight changes in the extracellular glutamate environment, such as impulse-triggered presynaptic release of glutamate.

The functions of FMRP in astrocytes have just begun to be understood, it is therefore likely that the selective loss of astroglial FMRP may affect targets/pathways other than GLT1 to enhance neuronal excitability. We then examined cortical neuronal excitability of layer 5 somatosensory pyramidal neurons in GLT1 ${ }^{+/-}$mice in which GLT1 expression is reduced by $50 \%$ and is comparable to the reduced GLT1 expression observed in Fmrl KO and astrocyte-specific cKO mice (Fig. $2 A)$. Although the complete deletion of GLT1 results in a $90-$ $100 \%$ increase in extracellular glutamate and severe excitotoxicity in GLT1 KO mice (Tanaka, 1997), extracellular glutamate levels only increase $20-30 \%$ in GLT1 ${ }^{+/-}$mice without inducing excitotoxicity (Takasaki et al., 2008). Interestingly, we found a $30 \%$ increased $(p<0.001)$ neuronal firing rate following $10 \mu \mathrm{M}$ DHK bath application (Fig. $3 C, D$ ) in GLT1 ${ }^{+/-}$ cortical slices compared with that of $10 \mu \mathrm{M}$ DHK-treated $\mathrm{GLT}^{+/+}$(WT) slices. The application of $50 \mu \mathrm{M}$ DHK also similarly increases neuronal firing rates in $\mathrm{GLT}^{+/-}$and $\mathrm{GLT}^{+/+}$cortical slices (Fig. $3 D$ ). These results suggest that a $50 \%$ reduction of GLT1 alone is indeed sufficient to increase neuronal sensitivity in response to a low dose of DHK treatment, supporting our notion that cortical pyramidal neurons from astrocyte-specific cKO mice could be more sensitive to an elevation of the extracellular glutamate environment, as a result of GLT1 dysregulation. The slightly lower increase $(30 \%)$ in neuronal firing rate in response to $10 \mu \mathrm{M}$ DHK treatment in $\mathrm{GLT} 1^{+/-}$mice compared with that $(45 \%)$ in astrocyte-specific cKO mice, also implicates the involvement of additional mechanisms in enhancing neuronal excitability in astrocyte-specific cKO mice.

To test whether the enhanced neuronal excitability can be rescued by the selective re-expression of FMRP in astrocytes, we next measured the firing rate of layer 5 pyramidal neurons following the application of $10 \mu \mathrm{M}$ DHK in astrocyte-specific cON (CreERT ${ }^{+} F_{m r l}{ }^{\text {loxP-neo/y }}$ ) and control (Cre ${ }^{\text {ERT- }}$ Fmr $\left.1^{\text {loxP-neo/y }}\right)$ cortical slices. We first found an increased firing rate of cortical pyramidal neurons in control slices (Fig. $3 E$ ), which is consistent with reduced functional GLT1 expression in these mice (Fig. 2G-J) and is similar to our previous observation in Fmr1 KO mice (Higashimori et al., 2013). In contrast, selective re-expression of FMRP in astrocytes signif- 

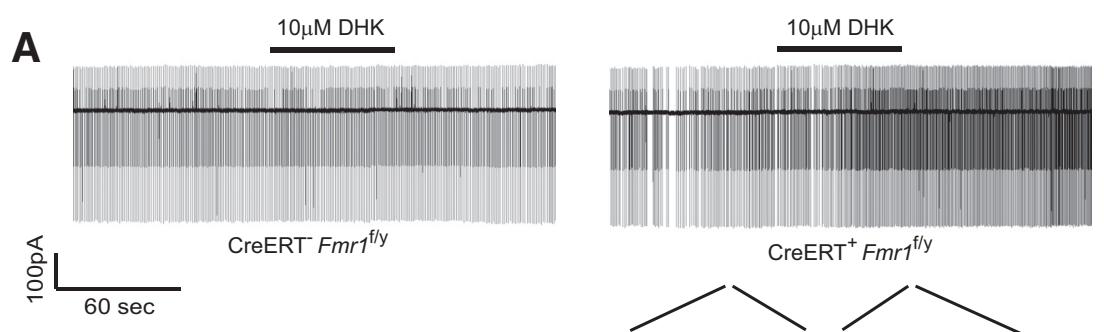

$\mathrm{CreERT}^{+} \mathrm{Fmr1}^{\mathrm{f} / \mathrm{y}}$
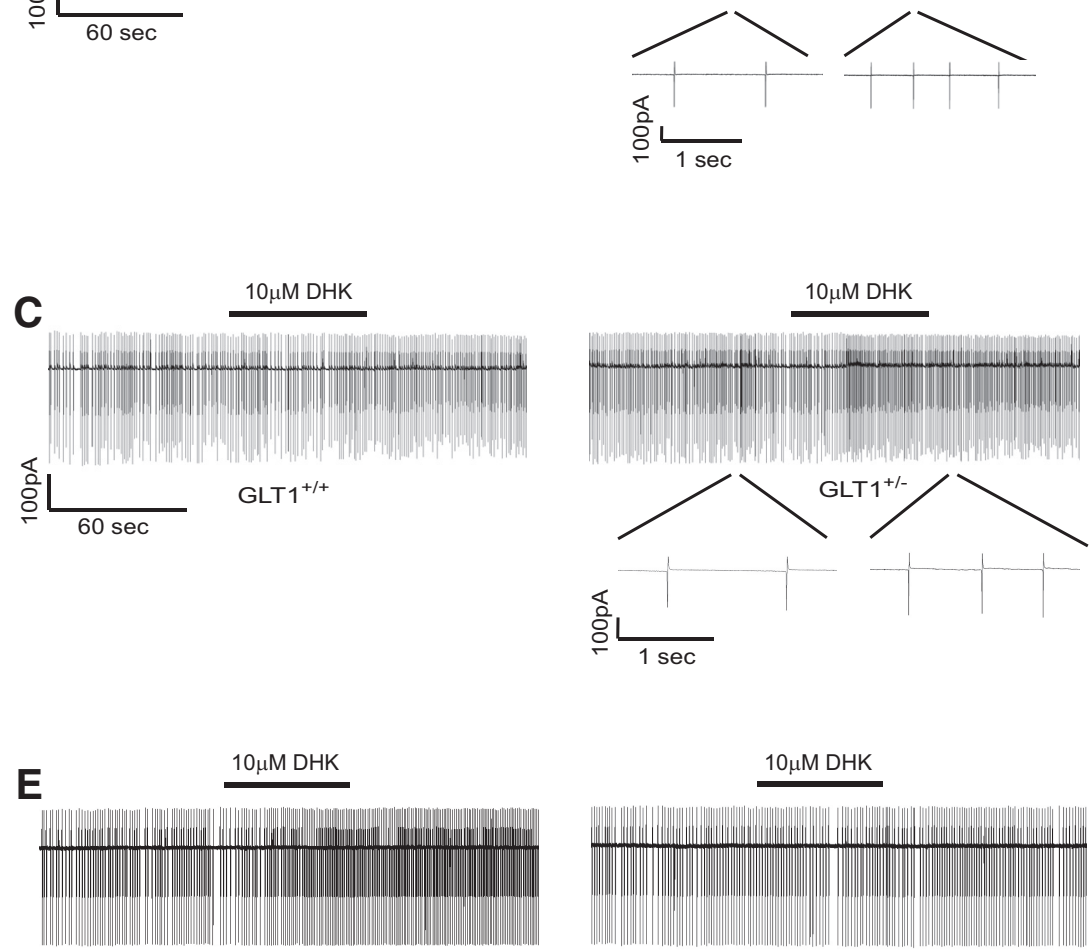

CreERT' Fmr1 $^{\text {loxP-Neo/y }}$

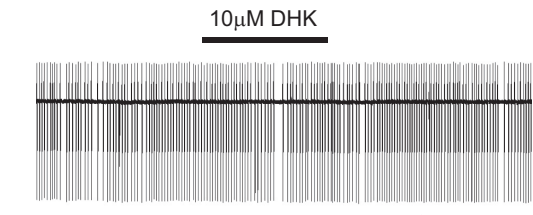

$\mathrm{CreERT}^{+}$Fmr1 ${ }^{\mathrm{loxP}-\mathrm{Neo} / \mathrm{y}}$

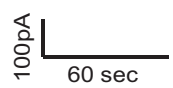

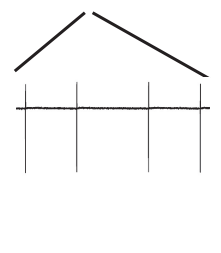
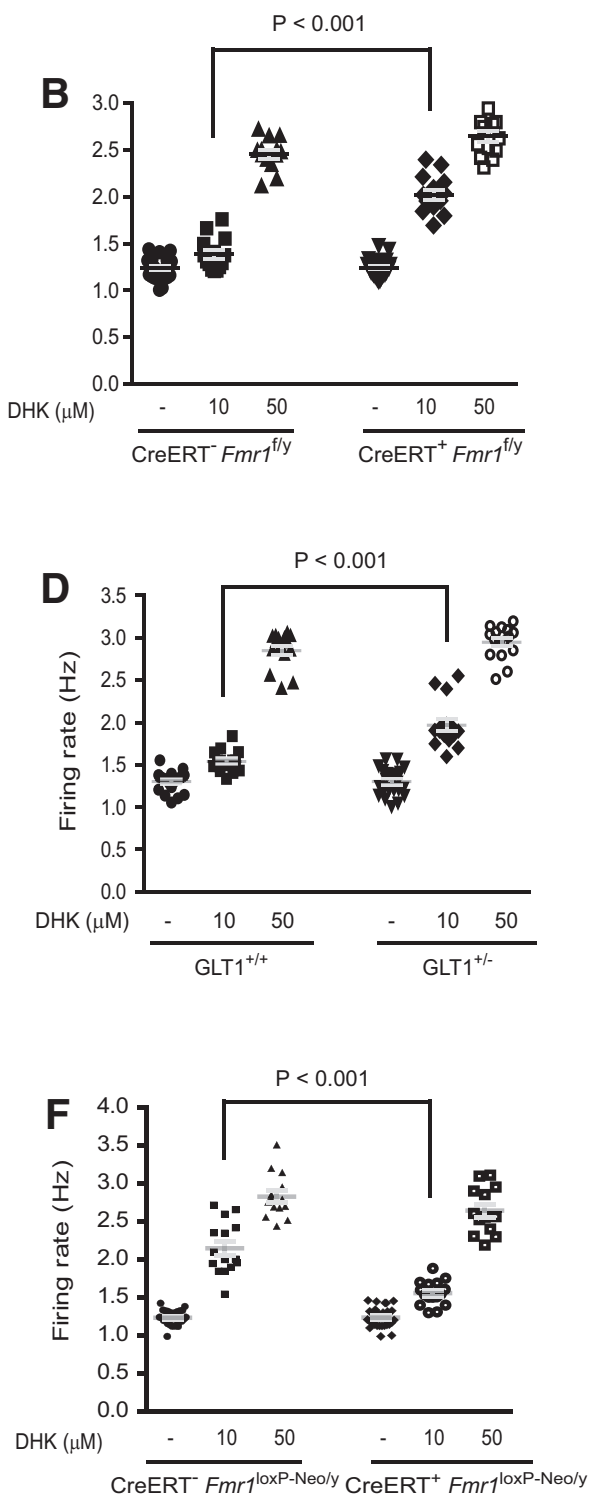

Figure 3. Dysregulated functional GLT1 expression enhances pyramidal neuronal excitability in cortex of astrocyte-specific cK0 mice. $\boldsymbol{A}$, A representative trace of neuronal firing recordings in layer 5 somatosensory neocortical neurons in astrocyte-specific CKO (CreERT ${ }^{+} \mathrm{Fmrl}^{\mathrm{f} / \mathrm{y}}$ ) and control (Cre ${ }^{\text {ERT }-} \mathrm{Fmr}^{\mathrm{f} / \mathrm{y}}$ ) cortical slices before and during bath application of

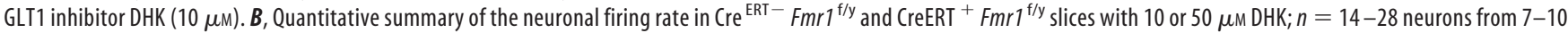
mice per group. $C$, A representative trace of neuronal firing recordings in layer 5 somatosensory neocortical neurons in $\mathrm{GLT1} 1^{+/+}$and $\mathrm{GLT1}{ }^{+/-}$cortical slices before and during the bath application of GLT1 inhibitor DHK (10 $\mu \mathrm{M})$. D, Quantitative summary of neuronal firing rate in GLT1 ${ }^{+/+}$and GLT1 $+/-$slices with 10 or $50 \mu \mathrm{M}$ DHK; $n=16-21$ neurons from 10 mice

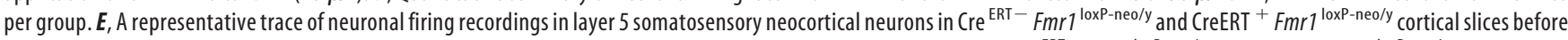
and during the bath application of GLT1 inhibitor DHK (10 $\mu \mathrm{m})$. F, Quantitative summary of the neuronal firing rate in Cre ${ }^{\text {ERT- }}$ Fmr $1^{\text {loxP-neo/y }}$ and CreERT ${ }^{+}$Fmr $1^{\text {loxP-neo/y }}$ slices with 10

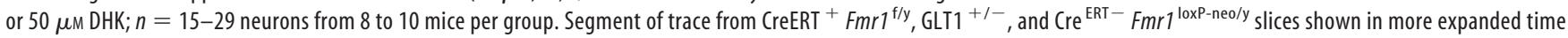
scale. The $p$ values were calculated using one-way ANOVA with post hoc Tukey's test.

icantly mitigates the $10 \mu \mathrm{M}$ DHK-induced increased firing rate of cortical pyramidal neurons in astrocyte-specific cON slices (Fig. $3 E, F$ ). Selective re-expression of FMRP in astrocytes also slightly but significantly decreases input resistance (Cre ${ }^{\text {ERT- }}$ Fmrl loxP-neo/y, $151.9 \pm 15.6 \mathrm{~m} \Omega$; $\mathrm{CreERT}^{+}$Fmrl loxP-neo/y, $136.6 \pm 10.2 \mathrm{~m} \Omega ; p=0.013$ ) and AP threshold (Cre ${ }^{\text {ERT }-}$ Fmrl ${ }^{\text {loxP-neo/y }},-35.3 \pm-1.7 \mathrm{mV}$; CreERT ${ }^{+}$Fmrl $1^{\text {loxP-neo/y }}$, $-33.8 \pm-1.7 \mathrm{mV} ; p=0.047)$, but not the RMP, capacitance, or AP spike height (Table 1). The control (Cre ${ }^{\text {ERT- }}$ Fmr1 ${ }^{\text {loxP-neo/y }}, 5 \%$ of WT FMRP levels) mice generally have very comparable basic electrophysiological parameters, as found in Fmr1 KO mice (Table 1). Although slightly decreased input resistance and AP threshold facilitates neuronal excitability in astrocyte-specific cON $\left(\mathrm{CreERT}^{+} \mathrm{Fmrl} \mathrm{l}^{\text {loxP-neo/y }}\right.$ ) mice, we still observed a reduced neuronal firing rate in astrocyte-specific cON cortical slices following $10 \mu \mathrm{M}$ DHK application, suggesting that astroglial FMRP re-expressioninduced restoration of GLT1 expression and function is more dominant in attenuating neuronal excitability. Overall, these results demonstrate that astroglial FMRP significantly regulates the functional expression of GLT1 in vivo. The dysregulation of GLT1 and the impairment of extracellular glutamate 

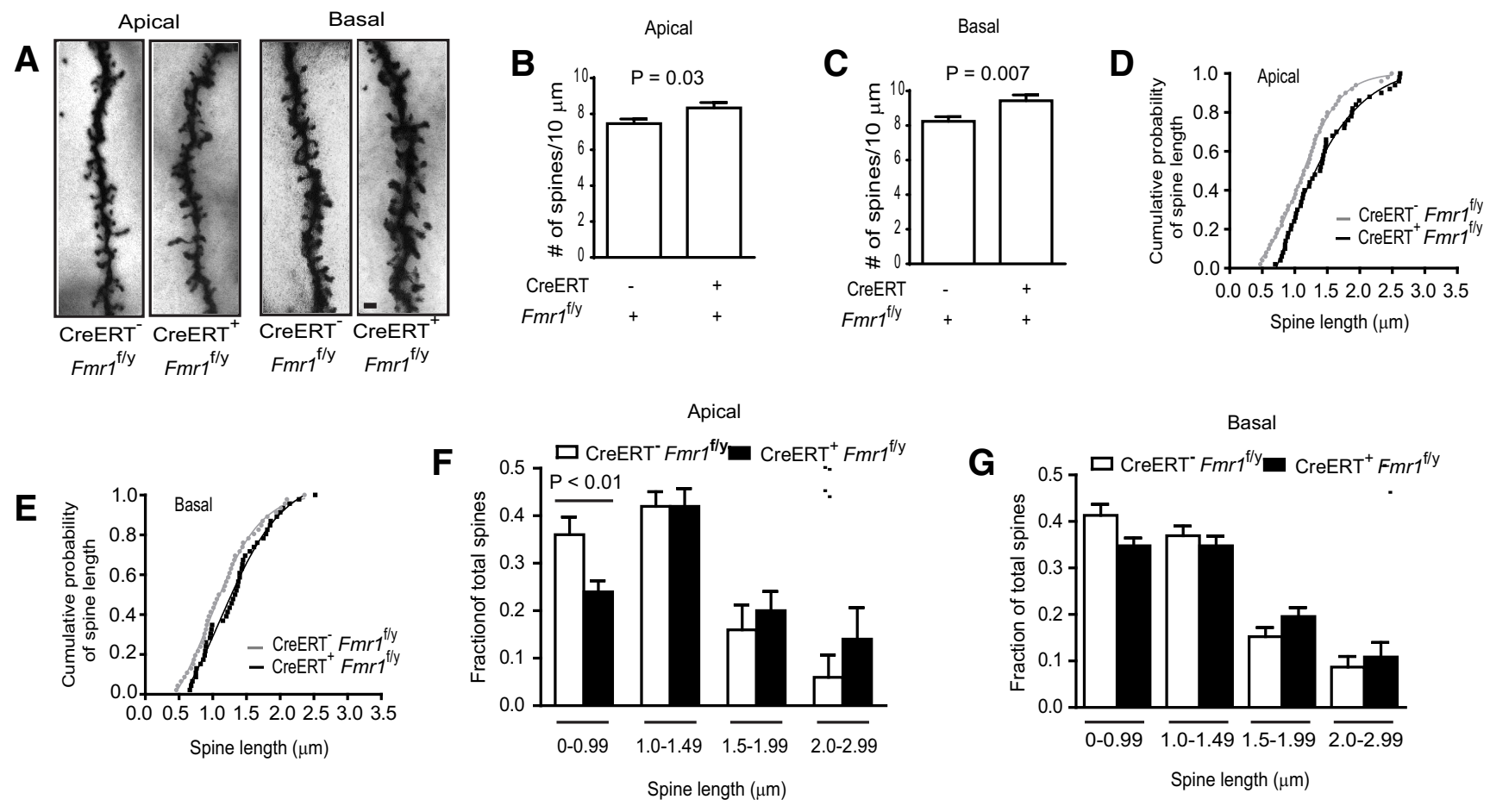

H

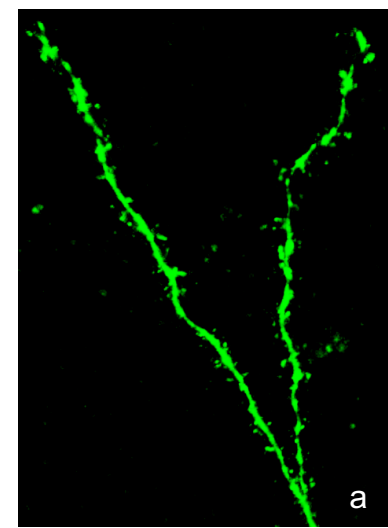

Confocal image

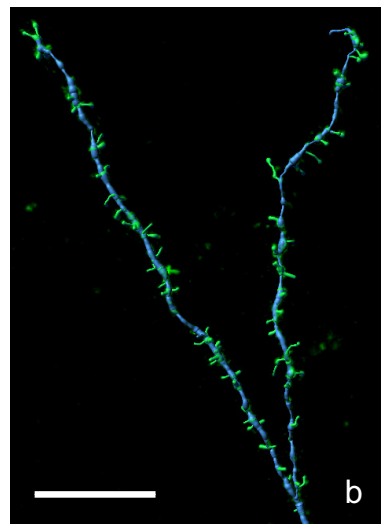

Imaris image
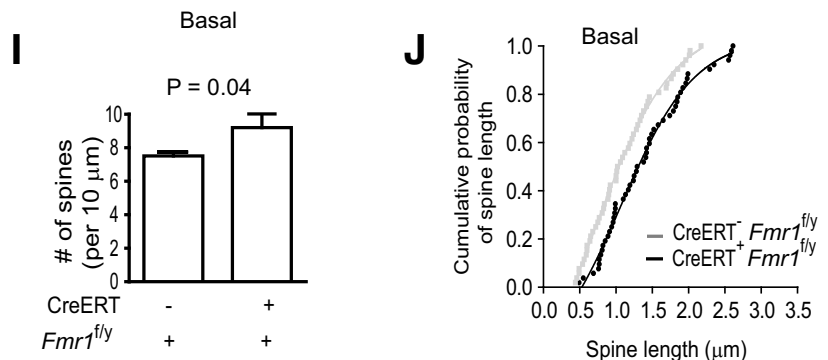

Figure 4. Dendritic spine morphology and density in cortical pyramidal neurons of astrocyte-specific cKO mice. $A$, Representative apical and basal dendrites from cortical layers $2 / 3$ of Cre ERT-

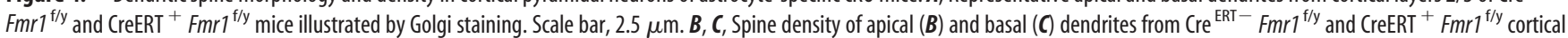

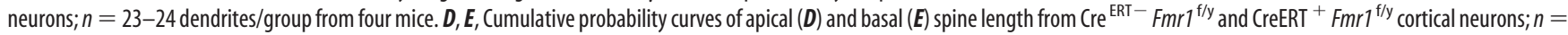

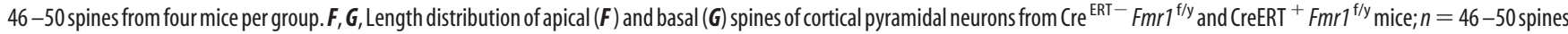
from four mice per group. $\boldsymbol{H}$, Representative confocal and filament tracing Imaris images of basal dendritic spines of cortical pyramidal neuron dye-filled with neurobiotin-488 tracer. $S c a l e$ bar, 10 $\mu \mathrm{m} . I$, Quantification of basal dendritic spines of dye-filled cortical neurons from Cre ${ }^{\mathrm{ERT}}-\mathrm{Fmr} \mathrm{T}^{\mathrm{f} / \mathrm{y}}$ and CreERT ${ }^{+} \mathrm{Fmr} 7^{\mathrm{ffy}}$ mice; $n=6$ dye-filled dendrites/group. $J$, Cumulative probability curves of basal spine length from dye-filled pyramidal neurons of $\mathrm{Cre}^{\mathrm{ERT}-} \mathrm{Fmr} \mathrm{f}^{\mathrm{fly}}$ and CreERT ${ }^{+} \mathrm{Fmr} \mathrm{f}^{\mathrm{f} / \mathrm{y}}$ cortical slices; $n=52$ spines from four mice per group. The $p$ values were calculated using the Student's $t$ test and two-way ANOVA with post hoc Bonferroni's test.

uptake, as a result of the selective loss of astroglial FMRP, could enhance neuronal excitability, especially in response to synaptically released glutamate in FXS models.

Astroglial FMRP modestly modulates synaptic structure and significantly regulates basal protein synthesis levels in cortical pyramidal neurons in vivo

Increased spine density with elongated immature spine morphology on pyramidal neurons has been consistently found in layers $2 / 3$ and 5 of the somatosensory cortex in both young ( $<6$ weeks age) and adult (8-12 weeks age) Fmr1 KO mice (Nimchinsky et al., 2001; Galvez and Greenough, 2005), as well as in human FXS brain samples (Rudelli et al., 1985; Hinton et al., 1991; Irwin et al.,
2000). Recent in vivo two-photon live imaging studies further revealed a delay in developmental turnover and reduced dynamics to sensory stimuli in dendritic spines of cortical pyramidal neurons of Fmr1 KO mice (Cruz-Martín et al., 2010; Pan et al., 2010), underlying their immature spine morphology and increased spine density. To investigate whether the selective loss of astroglial FMRP contributes to immature spine morphology, we determined spine density and length of layer $2 / 3$ cortical pyramidal neurons in astrocyte-specific cKO and control mice (P40P43) using a rapid Golgi staining procedure (Das et al., 2013). Representative spine morphology illustrated by Golgi staining is shown in Figure 4A. Subsequent quantification of spines from secondary apical and basal dendrites from confocal image stacks 

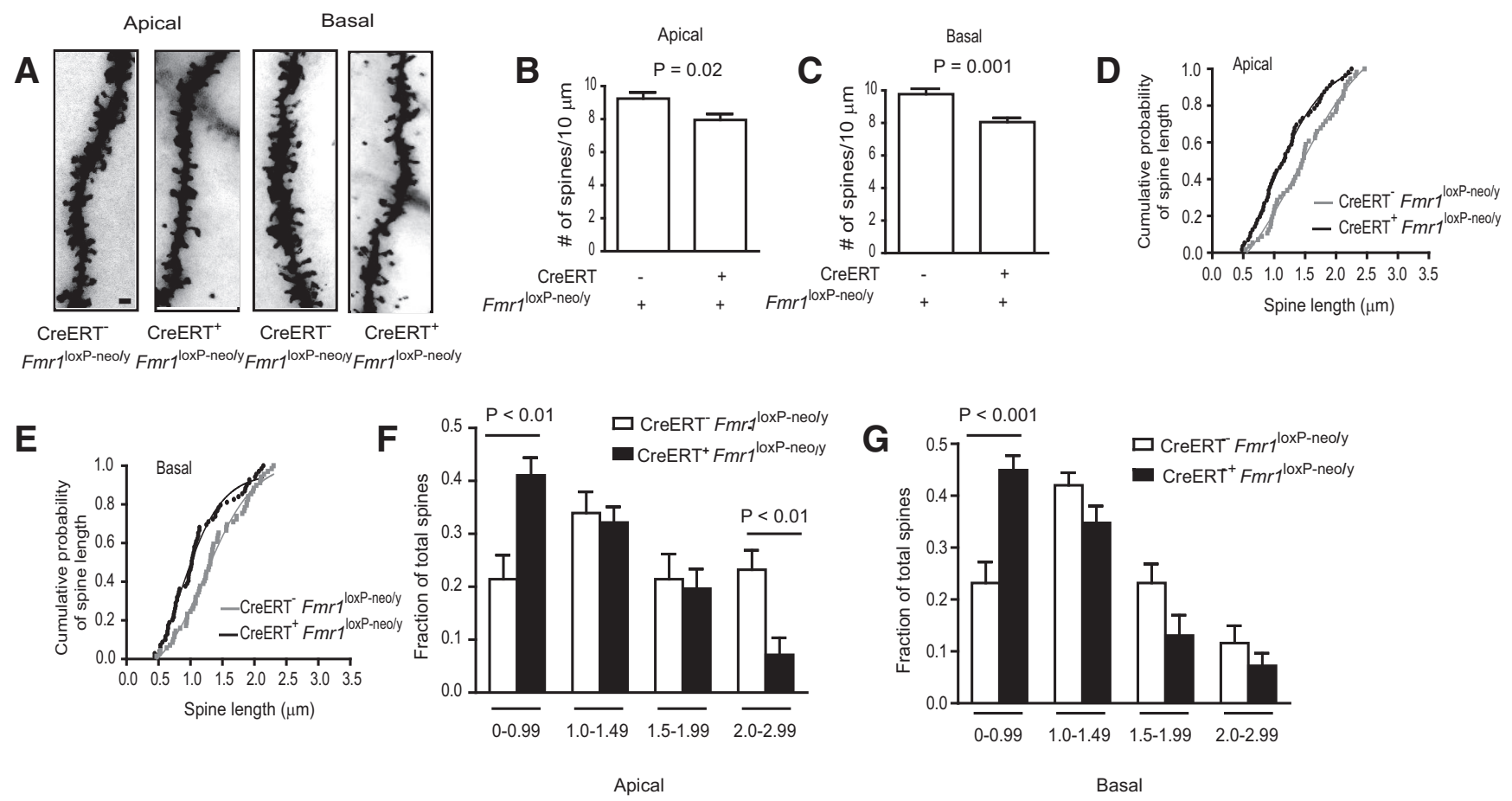

Figure 5. Dendritic spine morphology and density in cortical pyramidal neurons of astrocyte-specific cON mice. $A$, Representative apical and basal dendrites from cortical layers $2 / 3$ of

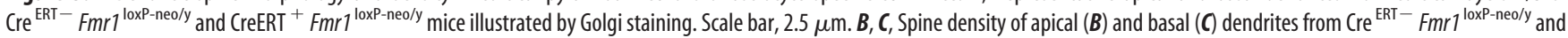
$\mathrm{CreERT}^{+} F m r 1^{\text {loxP-neo/y }}$ cortical neurons; $n=14$ dendrites/group from three mice. $\boldsymbol{D}, \boldsymbol{E}$, Cumulative probability curve of apical $(\boldsymbol{D})$ and basal $(\boldsymbol{E})$ spine length from Cre ${ }^{\text {ERT }-}$ Fmr $7^{\text {loxP-neo/y }}$ and $\mathrm{CreERT}^{+} F m r^{\text {loxP-neo/y }}$ cortical neurons; $n=56-69$ spines from three mice per group. Both the trend line and individual sample points were shown on a cumulative probability curve. $\boldsymbol{F}, \boldsymbol{G}$, Length distribution of apical $(\boldsymbol{F})$ and basal $(\boldsymbol{G})$ spines of cortical pyramidal neurons from Cre ${ }^{\text {ERT }-} F m r 1^{\text {loxP-neo/y }}$ and CreERT ${ }^{+} F m r 1^{\text {loxP-neo/y }}$ mice; $n=56-69$ spines/group. The $p$ values were determined using the Student's $t$ test and two-way ANOVA with post hoc Bonferroni's test.

shows that both apical and basal spine densities in astrocytespecific $\mathrm{cKO}$ mice are modestly but significantly increased (Fig. $4 B, C ; p=0.03$ and $p=0.007$, respectively). We further measured the spine length and generated the cumulative probability curve. As shown in Figure 4, $D$ and $E$, the cumulative probability curve shows a slight shift of spine length in astrocyte-specific cKO mice, particularly in apical spines. In particular, the percentage of apical spines with lengths in the range of $0-0.99 \mu \mathrm{m}$ is significantly decreased $(p<0.01)$ in astrocyte-specific cKO mice, while the number of spines with lengths in the range of $2-2.99 \mu \mathrm{m}$ is increased (Fig. $4 F$ ). The overall distribution of spine length in basal dendrites of pyramidal neurons in astrocyte-specific cKO cortex is similar to that in control mice (Fig. $4 G$ ), with a modest decrease in the number of shorter spines $(0-0.99 \mu \mathrm{m})$ and a slight increase in longer spines $(1.5-1.99 \mu \mathrm{m})$. To validate the Golgi-based quantification of dendritic spine density, we also dye filled patched cortical pyramidal neurons with neurobiotin- 488 tracer (Fig. 4Ha). Labeled dendritic spines are illustrated using the filament-tracing function in Imaris software for quantification (Fig. $4 \mathrm{Hb}$ ). As the tracer may not diffuse far enough to fully label apical dendritic spines using the dye-fill approach, we primarily focused on the quantification of basal dendritic spines following dye fill. As shown in Figure 4, $C$ and $I$, quantification of spine numbers per $10 \mu \mathrm{m}$ from the Golgi approach is slightly higher $(8.24 \pm 1.2$ in control) than that ( $7.36 \pm 0.5$ in control) from the dye-fill approach. However, both quantification approaches show significant differences $(p<0.007$ and $p<0.04$, respectively) in basal dendritic spine density between astrocytespecific cKO and control mice, confirming our analysis of dendritic spine with the Golgi-staining approach. In addition, we observed a more pronounced shift in the length of basal dendritic spines (Fig. $4 J$ ) from control to astrocyte-specific cKO mice using the dye-fill approach than the Golgi-staining approach. It is noted that the Golgi-staining approach examines only spine morphology and density at a particular time point, and the spine dynamics responding to stimuli in astrocyte-specific cKO mice remain to be determined using in vivo live imaging approaches.

We also examined dendritic spine morphology and density in astrocyte-specific cON $\left(\mathrm{CreERT}^{+} \mathrm{Fmrl}^{\text {loxP-neo/y }}\right)$ and control $\left(\right.$ CreERT $\left.^{-}{ }^{-} \mathrm{Fmrl}^{\text {loxp-neo/y }}\right)$ mice. Representative apical and basal spine morphology of cortical pyramidal neurons from these mice is shown in Figure 5A. Subsequent quantification found significantly ( $p=0.02$ and $p=0.001$, respectively) reduced apical and basal spine density in astrocyte-specific cON mice compared with the control mice (Fig. $5 B, C$ ). In addition, we measured spine length and generated cumulative probability curves. Both apical and basal spine length show a significant shift toward shorter spine length (Fig. $5 D, E$ ). In particular, the number of both apical and basal spines with lengths in the range of $0-0.99 \mu \mathrm{m}$ is significantly ( $p<0.01$ and $p<0.001$, respectively) increased, and the number of apical spines with lengths of $2-2.99 \mu \mathrm{m}$ is significantly $(p<0.01)$ decreased in astrocyte-specific cON mice (Fig. $5 F, G)$. These results suggest that selective re-expression of FMRP in astrocytes alone sufficiently and significantly mitigate the immature dendritic spine phenotype.

Increased protein synthesis has been previously described across brain regions, including the cortex, of Fmrl KO rodents (mice and rats; Qin et al., 2005; Till et al., 2015) and also in human FXS patients (Qin et al., 2013). It is considered a key downstream synaptic event contributing to various FXS phenotypes (Kelleher and Bear, 2008). Although the loss of neuronal FMRP abolishes its translation suppression function and thus increases protein 

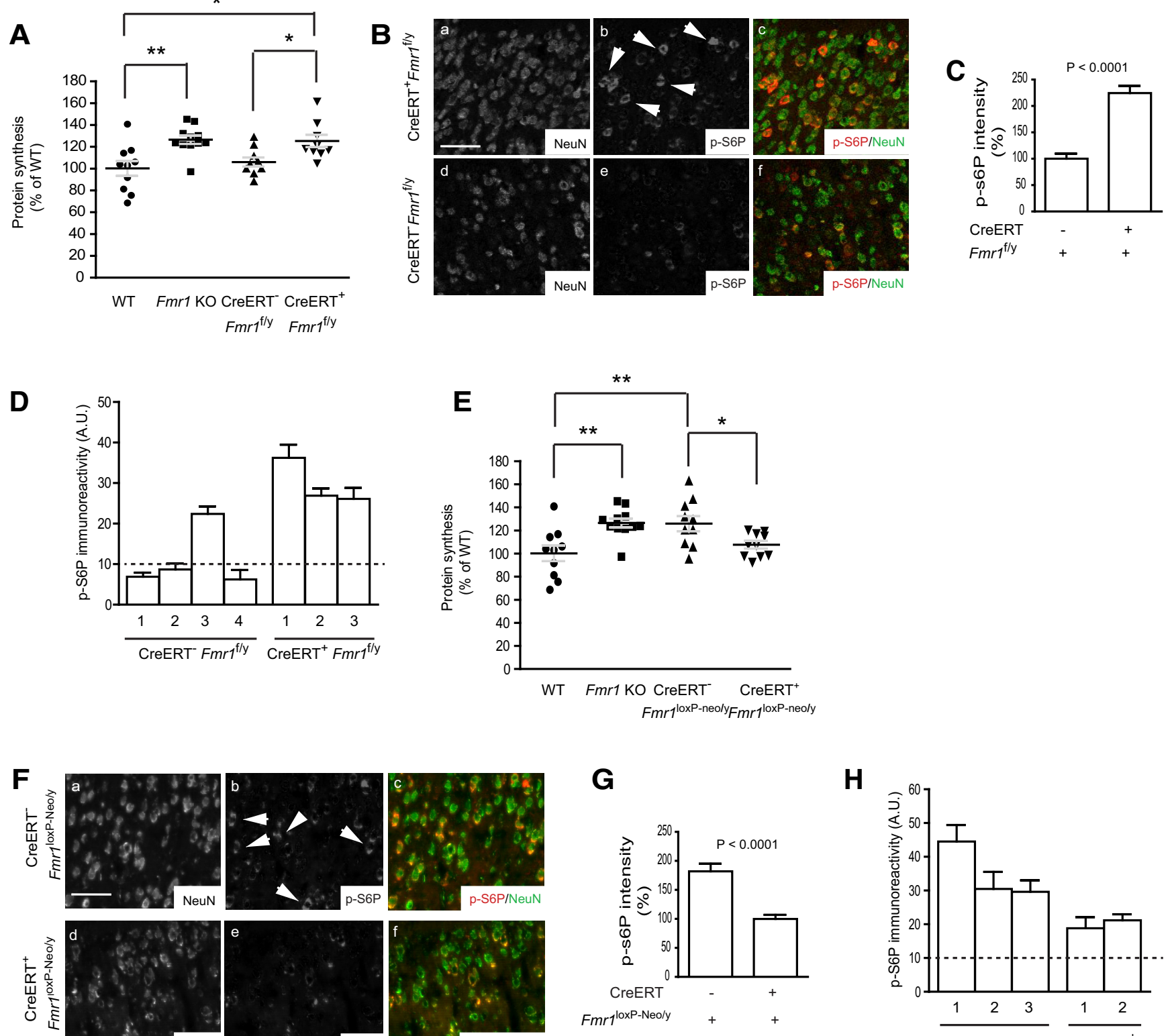

H

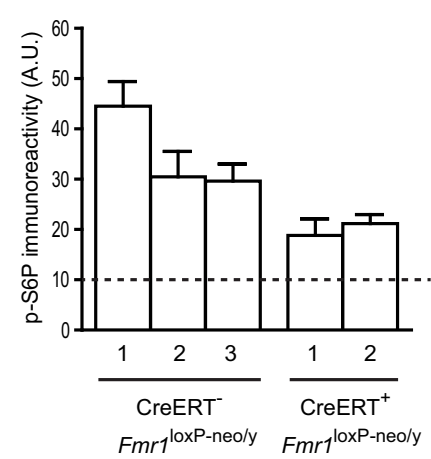

Figure 6. Altered protein synthesis in cortex of astrocyte-specific $\mathrm{CKO}$ and $\mathrm{CON}$ mice. $A$, Protein synthesis levels measured by metabolic labeling in $F m r 1 \mathrm{KO}$, astrocyte-specific cKO, and control

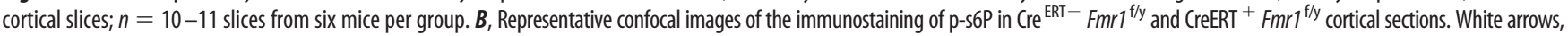
Prominent p-s6P-positive neurons. Scale bar, $50 \mu \mathrm{m}$. C, Quantification of p-s6P immunoreactivity in Cre ${ }^{\text {ERT }-~} F m r 1^{\mathrm{f} / y}$ and CreERT ${ }^{+} \mathrm{Fmr} 7^{\mathrm{f} / \mathrm{y}}$ cortical neurons; $n=65-124$ neurons from three to four mice per group. D, Immunoreactivity of p-s6P in cortical neurons from individual Cre ${ }^{\mathrm{ERT}-} \mathrm{Fmr}^{\mathrm{f} / \mathrm{y}}$ and $\mathrm{CreERT}^{+} \mathrm{Fmr}^{\mathrm{f} / \mathrm{y}}$ mice. E, Protein synthesis levels measured by metabolic labeling in astrocyte-specific cON and control mice; $n=10$ slices from more than five mice per group. $F$, Representative confocal images of the immunostaining of p-s6P in Cre ${ }^{\text {ERT }-} F m r 1^{\text {loxP-neo/y }}$ and CreERT ${ }^{+} F m r 1^{\text {loxP-neo/y }}$ cortical sections. White arrows, Prominent p-s6P-positive neurons. Scale bar, $50 \mu \mathrm{m}$. G, Quantification of p-s6Pimmunoreactivityin Cre ${ }^{\text {ERT }}-\mathrm{Fmr} 7^{\text {loxP-neo/y }}$ and CreERT ${ }^{+}$Fmr $1^{\text {loxP-neo/y }}$ cortical neurons; $n=55-58$ neurons from two to three mice per group. $\boldsymbol{H}$, Immunoreactivity of p-s6P in cortical neurons from individual $C \mathrm{Cre}^{\mathrm{ERT}-} \mathrm{Fmr} 7^{\text {loxP-neo/y }}$ and CreERT ${ }^{+} F m r 7^{\text {loxP-neo/y }}$ mice. A level of $10 \mathrm{~A}$.U. is defined as the background p-s6P immunoreactivity. The $p$ values were calculated using the Student's $t$ test and one-way ANOVA with post hoc Tukey's test: ${ }^{*} p<0.05 ;{ }^{* *} p<0.01$.

synthesis; whether there are non-neuronal mechanisms that alter neuronal protein synthesis levels in FXS remains unknown. We first measured basal protein synthesis levels in the somatosensory cortex slices of astrocyte-specific cKO and control mice using a metabolic labeling procedure, as previously described (Osterweil et al., 2010). The application of transcriptional and translational inhibitors ActD and CHX in cortical slices reduces overall protein synthesis by $85 \%$ (data not shown), validating the specificity of this procedure. In addition, protein synthesis levels are generally constant for up to $6 \mathrm{~h}$ after slice preparation (data not shown). By using this method, we found a $26 \%$ increase $(p<0.01$, Tukey's post hoc test from one-way ANOVA) of basal protein synthesis in Fmr1 KO cortical slices compared with WT cortical slices (Fig. $6 A$ ), which is consistent with previous reports (Qin et al., 2005). In astrocyte-specific cKO mice, basal protein synthesis increased $19 \%$ ( $p<0.05$, Tukey's post hoc test from one-way ANOVA) over that in control $\left(\right.$ CreERT $^{-}$Fmrl $^{\mathrm{f} / \mathrm{y}}$ ) mice (Fig. 6A). To specifically observe protein synthesis levels in cortical neurons in situ, we performed double immunostaining of p-s6P and $\mathrm{NeuN}$ on somatosensory cortical (layers $2 / 3$ ) sections from astrocyte-specific cKO and control mice (P30-P40). The s6P is a component of the $40 \mathrm{~S}$ ribosome, which, once phosphorylated at its C-terminal ser- 

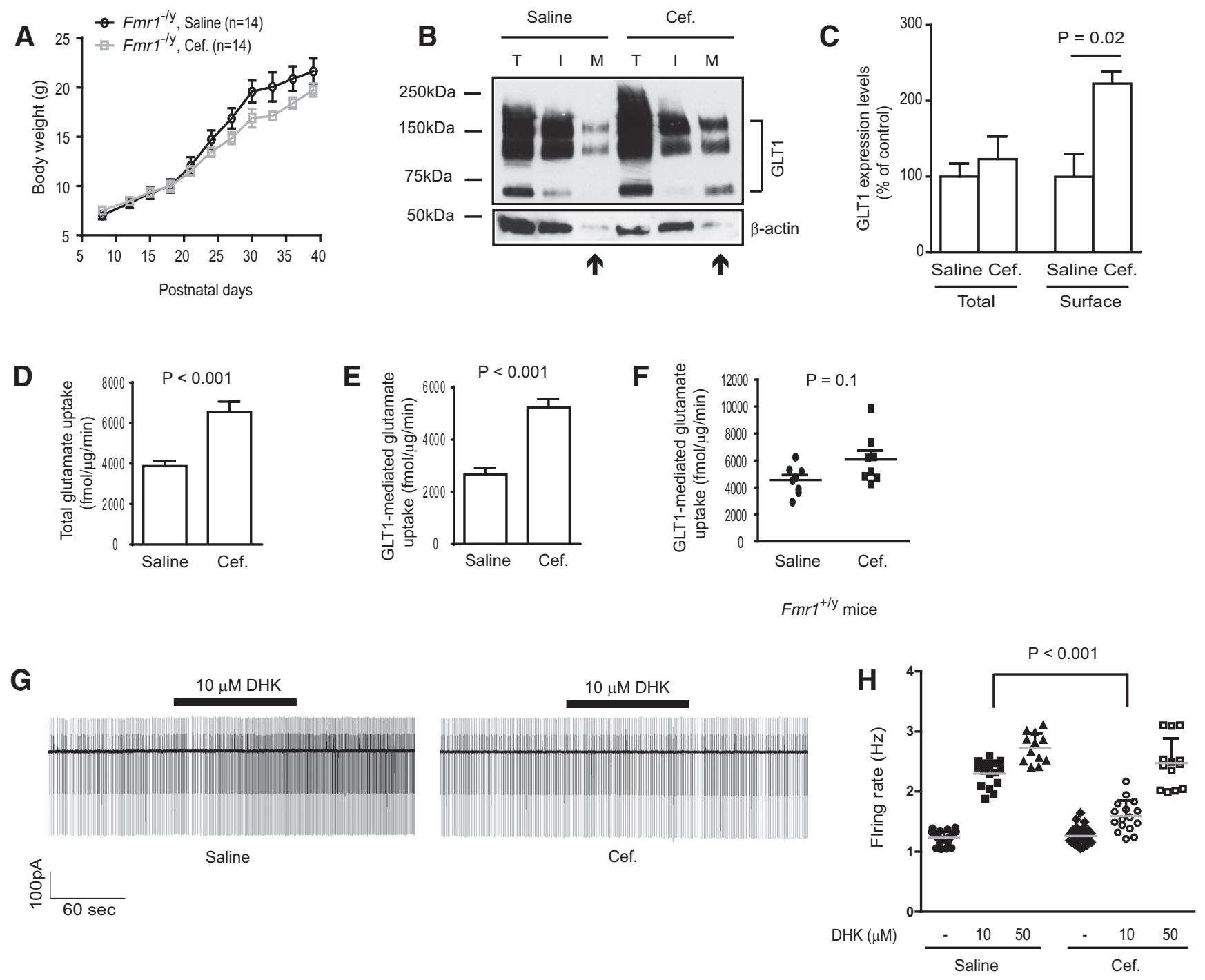

Figure 7. Pharmacological upregulation of functional GLT1 expression attenuates enhanced neuronal excitability in cortex of $F m r 1 \mathrm{KO}$ mice. $\boldsymbol{A}$, Body weight changes of saline- and Cef-injected Fmr $1 \mathrm{KO}$ mice during early postnatal development; $n=14$ mice/group. $B$, A representative immunoblot of GLT1 protein levels in total (T), intracellular (I), and membrane (M) fractions prepared from saline- or Cef-injected Fmr1 KO cortical tissues. C, Quantification of total and surface GLT1 protein levels in cortex of saline- or Cef-injected Fmr1 KO mice; $n=3$ mice/group. D, E, Total (D) and GLT1-mediated ( $\boldsymbol{E}$ ) glutamate uptake from saline- or Cef-injected $F m r 1 \mathrm{KO}$ cortical tissues; $n=7-10$ mice/group. $F$, GLT1-mediated functional glutamate uptake from saline- and Cef-injected WT $\left(F m r 1^{+/ y}\right)$ cortical tissues; $n=8$ mice/group. G, A representative trace of neuronal firing recordings in layer 5 somatosensory neocortical neurons in saline- or Cef-injected Fmr $1 \mathrm{KO}$ cortical slices before and during the bath application of GLT1 inhibitor DHK $(10 \mu \mathrm{m})$. $\boldsymbol{H}$, Quantitative summary of neuronal firing rates in saline- or Cef-injected $F m r 1 \mathrm{KO}$ cortical slices with 10 or $50 \mu \mathrm{m}$ DHK; $n=$ $12-28$ neurons from 7 to 10 mice per group. The $p$ values were determined using the Student's $t$ test, one-way ANOVA with post hoc Tukey's test, and two-way ANOVA with post hoc Bonferroni's test.

ine residues, enhances its affinity for the m7pppG cap during translation initiation (Roux et al., 2007). Thus, its phosphorylation is highly correlated with the level of mRNA translation (Peterson and Schreiber, 1998). Previous studies have found increased p-s6P levels in neurons through mTOR or ERK pathways in Fmr1 KO mice (Sharma et al., 2010). We observed clear p-s6P immunostaining signals (Fig. 6Bb, white arrows), especially in cortical neurons of astrocyte-specific cKO mice (Fig. $6 B b)$. Subsequent quantification of $\mathrm{p}$-s6 $\mathrm{P}$ from layer $2 / 3$ cortical neurons showed that the $\mathrm{p}$-s6P immunoreactivity increased more than twofold $(p<0.0001)$ in cortical neurons of astrocytespecific cKO mice compared with that in control mice (Fig. $6 C$ ). A closer examination of $\mathrm{p}$-s6 $\mathrm{P}$ levels in individual neurons from each mouse analyzed showed that p-s6P levels in astrocytespecific cKO, but not control, cortical neurons are generally higher than the background p-s6P level [defined as 10 arbitrary units (A.U.); Fig. 6D], further indicating that cortical neurons from astrocyte-specific cKO mice undergo more active basal protein synthesis than that in cortical neurons of control mice.

To test whether selective re-expression of FMRP in astrocytes alters basal protein synthesis, we next performed a metabolic labeling assay in cortical slices prepared from astrocyte-specific cON and control mice. Similar to Fmrl KO mice, the control $\left(\mathrm{Cre}^{-} \mathrm{Fmrl}^{\text {loxP-neo/y }}\right)$ mice have significantly increased $(26 \%$ compared with WT mice; Fig. $6 E$ ) protein synthesis levels, presumably as a result of the significantly reduced FMRP levels $(\sim 5 \%$ of $\mathrm{WT})$ in these mice. The re-expression of FMRP in astrocytes, however, effectively and significantly $(p<0.05$ and $p<$ 0.01 , respectively, Tukey's post hoc test from one-way ANOVA) reduces basal protein synthesis levels in astrocyte-specific cON cortical slices when compared with control ( $\mathrm{Cre}^{-} \mathrm{Fmrl} \mathrm{l}^{\text {loxP-neo/y }}$ ) or Fmr1 KO cortical slices (Fig. 6E), as measured by metabolic labeling. We further measured the p-s6P immunoreactivity in cortical neurons and found that indeed p-s6P levels are also sig- 

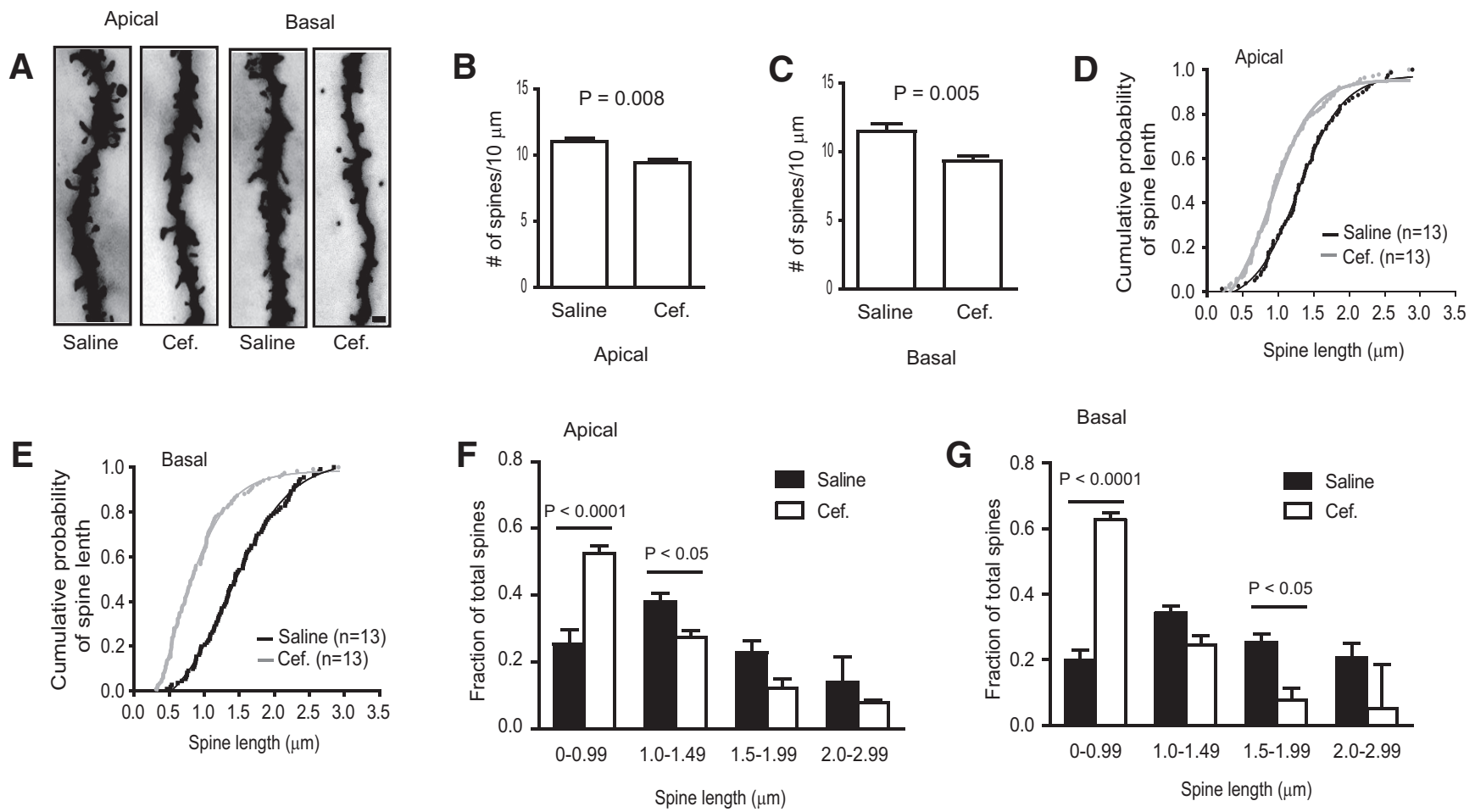

Figure 8. Pharmacological upregulation of functional GLT1 expression corrects spine abnormalities in cortex of $F m r 1 \mathrm{KO}$ mice. $\boldsymbol{A}$, Representative apical and basal dendrites from cortical layer $2 / 3$ of saline- or Cef-injected Fmr 1 KO cortical slices illustrated by Golgi staining. Scale bar, $2.5 \mu \mathrm{m} . \boldsymbol{B}, \boldsymbol{C}$, Spine density of apical (B) and basal (C) dendrites from saline- or Cef-injected Fmr 1 KO cortical neurons; $n=13$ dendrites from four mice per group. $\boldsymbol{D}, \boldsymbol{E}$, Cumulative probability curve of apical $(\boldsymbol{D})$ and basal $(\boldsymbol{E})$ spine length from saline- or Cef-injected $F m r 1 \mathrm{~K} 0$ cortical neurons; $n=79-140$ spines from four mice per group. Both the trend line and individual sample points are shown on cumulative probability curve. $\boldsymbol{F}, \boldsymbol{G}$, Length distribution of apical $(\boldsymbol{F})$ and basal $(\boldsymbol{G})$ spines of cortical pyramidal neurons in saline- and Cef-injected Fmr $1 \mathrm{KO}$ mice; $n=79-140$ spines from four mice per group. The $p$ values were determined using the Student's $t$ test, two-way ANOVA, and post hoc Bonferroni's test.

nificantly $(p<0.0001)$ decreased in cortical neurons of astrocyte-specific cON mice when compared with those in control (Cre ${ }^{-}$Fmr1 ${ }^{\text {loxP-neo/y }}$ ) mice (Fig. 6F, G), which is consistent with the metabolic labeling results from these mice. Interestingly, p-s6P levels in individual cortical neurons analyzed from both control ( $\left.\mathrm{Cre}^{-} \mathrm{Fmrl}^{\text {loxP-neo/y }}\right)$ and astrocyte-specific cON mice are similarly likely to be above the background p-s6P level (10 A.U.; Fig. $6 H$ ), suggesting that the loss of FMRP in other CNS cells is also important for elevated basal protein translation.

\section{Upregulation of functional GLT1 expression attenuates neuronal excitability and dendritic spine phenotypes in cortex of Fmr1 KO mice}

Our previous studies (Higashimori et al., 2013) and the results above demonstrate that dysregulated GLT1 expression and impaired extracellular glutamate uptake enhance neuronal excitability in Fmr1 KO mouse models. To further test whether GLT1 dysregulation contributes to FXS phenotypes, we examined FXSrelated synaptic phenotypes in Fmr1 KO mice following GLT1 upregulation. Cef, a Food and Drug Administration-approved antibiotic that is permeable to the blood-brain barrier, has been previously identified to increase GLT1/EAAT2 expression and glutamate uptake (Rothstein et al., 2005). To demonstrate that ceftriaxone injections indeed increase the surface expression of GLT1 protein and functional glutamate uptake in Fmr1 KO mice, we performed a biotinylation assay on cortical slices from salineor ceftriaxone-injected (from P7 to P28) Fmr1 KO mice. The 3-week-long ceftriaxone injections (200 mg/kg, i.p., daily) were well tolerated without inducing observable adverse effects in mice. We first observed a significantly decreased growth rate of body weight in ceftriaxone-injected Fmrl KO mice compared with saline-injected Fmr1 mice from P25 to P40 (Fig. 7A), suggesting a suppression of accelerated prepubescent growth that is often observed in children with FXS and in Fmr1 KO mice (Loesch et al., 1995). Interestingly, although ceftriaxone injections slightly increase total GLT1 levels (15\%), the surface expression levels of GLT1 protein are increased $220 \%(p=0.02)$ compared with that in saline injections (Fig. $7 B, C$ ). Ceftriaxone injections also significantly increase total and GLT1-mediated glutamate uptake to a level comparable with that in WT mice (6000 and $4000 \mathrm{fmol} / \mu \mathrm{g} / \mathrm{min}$, respectively; Fig. $7 D, E)$. In contrast, ceftriaxone injections induce only a modest and insignificant increase $(p=0.1)$ in GLT1-mediated glutamate uptake in WT mice (Fig. $7 F$ ). We have previously found that Fmr1 KO cortical neurons are more sensitive to a low dose $(10 \mu \mathrm{M})$ of DHK application with significantly increased firing rates (Higashimori et al., 2013). To functionally test whether ceftriaxone injections mitigate enhanced neuronal excitability, we examined neuronal excitability in Fmr1 KO cortical slices following sham or ceftriaxone injections. As shown in Figure $7 G, H$, although the neuronal firing rate increased twofold in response to $10 \mu \mathrm{M}$ DHK application in sham-injected Fmrl KO mice, the neuronal firing rate in response to $10 \mu \mathrm{M}$ DHK application is significantly lower $(p<$ 0.001 ) and is only slightly greater than that of the control (no DHK treatment) in ceftriaxone-injected Fmr1 KO mice.

We next examined the dendritic spine length and density in ceftriaxone-injected Fmrl KO mice. Representative secondary apical and basal dendritic spine images illustrated by Golgi staining are shown in Figure $8 A$. Quantification of dendritic spine numbers from layers $2 / 3$ reveals that ceftriaxone injections are 
able to significantly ( $p=0.008$ and $p=0.005$, respectively) reduce both apical and basal spine density (Fig. $8 B, C$ ). In addition, the overall distribution of spine length in ceftriaxone-injected Fmr1 KO mice, indicated by cumulative probability curves (Fig. $8 D, E)$, is significantly shifted toward shorter spines, especially for basal dendritic spines. The breakdown of spine length further suggests that the percentage of both apical and basal spines within the range of $0-0.99 \mu \mathrm{m}$ is particularly increased $(p<0.0001)$, and the number of longer spines, especially within the 1.5-1.99 and 2-2.99 $\mu \mathrm{m}$ ranges, is decreased in ceftriaxone-injected Fmr1 KO mice (Fig. $8 F, G$ ). Together, these results demonstrate that the restoration of glutamate uptake and the rebalance of the extracellular glutamate environment sufficiently mitigate synaptic phenotypes in Fmr1 KO mice.

\section{Discussion}

In the current study, we generated astrocyte-specific $\mathrm{KO}$ (cKO) and restoration $(\mathrm{cON})$ mice to study astrocyte dysfunctions in response to the selective loss of astroglial FMRP and in vivo modulation of FXS synaptic phenotypes by astroglial FMRP. Our examination of astrocyte glutamate uptake function and several FXS phenotypes in the cortex of these mice provides compelling evidence that the selective loss of astroglial FMRP contributes to cortical synaptic deficits (i.e., enhanced neuronal excitability, abnormalities in spine density/morphology, and increased basal protein synthesis levels in FXS), likely through the dysregulated astroglial glutamate transporter GLT1 and impaired glutamate uptake. We also showed that selective re-expression of FMRP in astrocytes is sufficient only to rescue the dysregulated functional expression of GLT1 and mitigate FXS-related synaptic phenotypes. These results demonstrate previously undescribed astrocyte-mediated mechanisms in the pathogenesis of FXS in the cortex. In addition, these results expand our understanding of FMRP functions in the CNS, especially its uniquely positive roles in regulating GLT1 expression in cortical astrocytes.

Whether and how the loss of astroglial FMRP in vivo contributes to FXS pathogenesis remain essentially unknown. Astrocytes are known to express unique transporters and channels for actively regulating the homeostatic environment in the CNS. In particular, glutamate transporter subtype GLT1 (human excitatory amino acid transporter 2 ) is strongly induced in astrocytes during early postnatal development, becoming the physiologically dominant glutamate transporter in the forebrain (Furuta et al., 1997). GLT1 is typically concentrated on the plasma membranes of perisynaptic astroglial processes where they tightly control extracellular glutamate levels from excitatory synapses (Huang and Bergles, 2004). We found that GLT1 expression (and functional glutamate uptake) is significantly reduced in the cortex of Fmr1 KO mice (Higashimori et al., 2013) and astrocytespecific cKO mice, and at least in some human postmortem FXS cortical tissues. In addition, the loss of presynaptic FMRP abolishes its binding with the BK channel $\beta 4$ subunit, leading to excessive AP broadening during repetitive activity, enhanced presynaptic calcium influx, and elevated neurotransmitter release in Fmr1 KO mice (Deng et al., 2013). These observations indicate an elevated (but not excitotoxic) extracellular glutamate environment in Fmr1 KO mice, which may potentiate neuronal synaptic activation and downstream signaling events, such as protein synthesis. In fact, elevated metabotropic glutamate receptor 5 (mGluR5)-dependent basal protein synthesis has been observed in Fmr1 KO mice (Osterweil et al., 2010) and the inhibition of mGluR5 in Fmr1 KO mice can effectively attenuate typical FXS phenotypes (Dölen et al., 2007; Michalon et al.,
2012). Although it is possible that mGluR5 becomes hypersensitive (Osterweil et al., 2010), our current study suggests that alteration of the extracellular glutamate environment may also contribute to the mGluR5 activation in FXS. As altered spine morphology and protein synthesis are typically downstream events of abnormal glutamate receptor activation, the full restoration of extracellular glutamate uptake resulting from the selective re-expression of FMRP in astrocytes, is likely to have significant rescue effects. Indeed, we observed pronounced mitigation effects on several FXS phenotypes examined in our FXS models. Therefore, a dysregulated GLT1 expression and impaired extracellular glutamate uptake, as a result of the selective loss of astroglial FMRP, represents a new upstream pathway in FXS pathogenesis.

Astrocytes are known to undergo an important postnatal maturation phase in which a uniquely ramified morphology is acquired (Freeman, 2010; Morel et al., 2014), and important functional genes are induced within 3 weeks postnatally (in mice). In addition, developing astrocytes actively regulate synaptogenesis and the formation of functional synapses (Clarke and Barres, 2013). Although immature dendrite morphology and altered synaptic functions have been implicated in FXS (and other neurodevelopmental disorders), whether the developmental induction of these functional genes and developing astrocyte-dependent synaptogenic pathways is altered remains to be examined. Our current study, by examining the astrocyte GLT1 expression and FXS phenotypes in astrocytespecific Fmr 1 cKO and cON mice, provides in vivo evidence that astrocyte development is impaired in response to the lack of (astroglial) FMRP in FXS models, and this impairment contributes to FXS pathogenesis. Whether the selective loss of neuronal FMRP alters astrocyte development and functions in vivo remains unknown, largely due to the lack of mice in which Fmr1 is selectively deleted in neurons. Previously, mice with selective deletion of Fmrl in Purkinje neurons and adult neural stem cells have been generated (Koekkoek et al., 2005; Guo et al., 2011); however, whether astrocytes become dysfunctional in these mice was not examined. Given the diverse and active modulatory functions that astrocytes perform in the CNS, alterations of astrocyte functions may provide new avenues for alternative therapeutic interventions. It is also interesting to further test whether the restoration of FMRP in astrocytes after postnatal development would alter FXS phenotypes.

\section{References}

Amiri A, Sanchez-Ortiz E, Cho W, Birnbaum SG, Xu J, McKay RM, Parada LF (2014) Analysis of FMR1 deletion in a subpopulation of post-mitotic neurons in mouse cortex and hippocampus. Autism Res 7:60-71. CrossRef Medline

Bakker CE, Verheij C, Willemsen R, van der Helm R, Oerlemans F, Vermey M, Bygrave A, Hoogeveen AT, Oostra BA, Reyniers E, D’Hooge R, Cras P, Van Velzen D, Nagels G, Martin JJ, De Deyn PP, Darby JK, Willems PJ (1994) Fmr1 knockout mice: a model to study fragile X mental retardation. Cell 78:23-33. Medline

Bassell GJ, Warren ST (2008) Fragile X syndrome: loss of local mRNA regulation alters synaptic development and function. Neuron 60:201-214. CrossRef Medline

Broekman ML, Comer LA, Hyman BT, Sena-Esteves M (2006) Adenoassociated virus vectors serotyped with AAV8 capsid are more efficient than AAV-1 or -2 serotypes for widespread gene delivery to the neonatal mouse brain. Neuroscience 138:501-510. CrossRef Medline

Cahoy JD, Emery B, Kaushal A, Foo LC, Zamanian JL, Christopherson KS, Xing Y, Lubischer JL, Krieg PA, Krupenko SA, Thompson WJ, Barres BA (2008) A transcriptome database for astrocytes, neurons, and oligoden- 
drocytes: a new resource for understanding brain development and function. J Neurosci 28:264-278. CrossRef Medline

Clarke LE, Barres BA (2013) Emerging roles of astrocytes in neural circuit development. Nat Rev Neurosci 14:311-321. CrossRef Medline

Comery TA, Harris JB, Willems PJ, Oostra BA, Irwin SA, Weiler IJ, Greenough WT (1997) Abnormal dendritic spines in fragile X knockout mice: maturation and pruning deficits. Proc Natl Acad Sci U S A 94: 5401-5404. CrossRef Medline

Cruz-Martín A, Crespo M, Portera-Cailliau C (2010) Delayed stabilization of dendritic spines in fragile X mice. J Neurosci 30:7793-7803. CrossRef Medline

Darnell JC, Jensen KB, Jin P, Brown V, Warren ST, Darnell RB). (2001) Fragile $\mathrm{X}$ mental retardation protein targets $\mathrm{G}$ quartet mRNAs important for neuronal function. Cell 107:489-499. CrossRef Medline

Das G, Reuhl K, Zhou R (2013) The Golgi-Cox method. Methods Mol Biol 1018:313-321. CrossRef Medline

Deng PY, Rotman Z, Blundon JA, Cho Y, Cui J, Cavalli V, Zakharenko SS, Klyachko VA (2013) FMRP regulates neurotransmitter release and synaptic information transmission by modulating action potential duration via BK channels. Neuron 77:696-711. CrossRef Medline

Dölen G, Osterweil E, Rao BS, Smith GB, Auerbach BD, Chattarji S, Bear MF (2007) Correction of fragile X syndrome in mice. Neuron 56:955-962. CrossRef Medline

Freeman MR (2010) Specification and morphogenesis of astrocytes. Science 330:774-778. CrossRef Medline

Furuta A, Rothstein JD, Martin LJ (1997) Glutamate transporter protein subtypes are expressed differentially during rat CNS development. J Neurosci 17:8363-8375. Medline

Galvez R, Greenough WT (2005) Sequence of abnormal dendritic spine development in primary somatosensory cortex of a mouse model of the fragile X mental retardation syndrome. Am J Med Genet A 135:155-160. CrossRef Medline

Ge WP, Miyawaki A, Gage FH, Jan YN, Jan LY (2012) Local generation of glia is a major astrocyte source in postnatal cortex. Nature 484:376-380. CrossRef Medline

Guo W, Allan AM, Zong R, Zhang L, Johnson EB, Schaller EG, Murthy AC, Goggin SL, Eisch AJ, Oostra BA, Nelson DL, Jin P, Zhao X (2011) Ablation of Fmrp in adult neural stem cells disrupts hippocampus-dependent learning. Nat Med 17:559-565. CrossRef Medline

Heiman M, Schaefer A, Gong S, Peterson JD, Day M, Ramsey KE, SuárezFariñas M, Schwarz C, Stephan DA, Surmeier DJ, Greengard P, Heintz N (2008) A translational profiling approach for the molecular characterization of CNS cell types. Cell 135:738-748. CrossRef Medline

Higashimori H, Morel L, Huth J, Lindemann L, Dulla C, Taylor A, Freeman M, Yang Y (2013) Astroglial FMRP-dependent translational downregulation of mGluR5 underlies glutamate transporter GLT1 dysregulation in the fragile X mouse. Hum Mol Genet 22:2041-2054. CrossRef Medline

Hinton VJ, Brown WT, Wisniewski K, Rudelli RD (1991) Analysis of neocortex in three males with the fragile X syndrome. Am J Med Genet 41:289-294. CrossRef Medline

Huang YH, Bergles DE (2004) Glutamate transporters bring competition to the synapse. Curr Opin Neurobiol 14:346-352. CrossRef Medline

Irwin SA, Galvez R, Greenough WT (2000) Dendritic spine structural anomalies in fragile-X mental retardation syndrome. Cereb Cortex 10: 1038-1044. CrossRef Medline

Jacobs S, Doering LC (2010) Astrocytes prevent abnormal neuronal development in the fragile X mouse. J Neurosci 30:4508-4514. CrossRef Medline

Kazdoba TM, Leach PT, Silverman JL, Crawley JN (2014) Modeling fragile $\mathrm{X}$ syndrome in the Fmrl knockout mouse. Intractable Rare Dis Res 3:118-133. CrossRef Medline

Kelleher RJ 3rd, Bear MF 2008 The autistic neuron: troubled translation? Cell 135:401-406. CrossRef Medline

Koekkoek SK, Yamaguchi K, Milojkovic BA, Dortland BR, Ruigrok TJ, Maex R, De Graaf W, Smit AE, VanderWerf F, Bakker CE, Willemsen R, Ikeda T, Kakizawa S, Onodera K, Nelson DL, Mientjes E, Joosten M, De Schutter E, Oostra BA, Ito M, et al (2005) Deletion of FMR1 in Purkinje cells enhances parallel fiber LTD, enlarges spines, and attenuates cerebellar eyelid conditioning in fragile X syndrome. Neuron 47:339-352. CrossRef Medline

Loesch DZ, Huggins RM, Hoang NH (1995) Growth in stature in fragile X families: a mixed longitudinal study. Am J Med Genet 58:249-256. CrossRef Medline

Madisen L, Zwingman TA, Sunkin SM, Oh SW, Zariwala HA, Gu H, Ng LL, Palmiter RD, Hawrylycz MJ, Jones AR, Lein ES, Zeng H (2010) A robust and high-throughput Cre reporting and characterization system for the whole mouse brain. Nat Neurosci 13:133-140. CrossRef Medline

Meredith RM, Holmgren CD, Weidum M, Burnashev N, Mansvelder HD (2007) Increased threshold for spike-timing-dependent plasticity is caused by unreliable calcium signaling in mice lacking fragile $\mathrm{X}$ gene FMR1. Neuron 54:627-638. CrossRef Medline

Michalon A, Sidorov M, Ballard TM, Ozmen L, Spooren W, Wettstein JG, Jaeschke G, Bear MF, Lindemann L (2012) Chronic pharmacological mGlu5 inhibition corrects fragile X in adult mice. Neuron 74:49-56. CrossRef Medline

Mientjes EJ, Nieuwenhuizen I, Kirkpatrick L, Zu T, HoogeveenWesterveld M, Severijnen L, Rifé M, Willemsen R, Nelson DL, Oostra BA (2006) The generation of a conditional Fmrl knock out mouse model to study Fmrp function in vivo. Neurobiol Dis 21:549-555. CrossRef Medline

Morel L, Higashimori H, Tolman M, Yang Y (2014) VGluT1 ${ }^{+}$neuronal glutamatergic signaling regulates postnatal developmental maturation of cortical protoplasmic astroglia. J Neurosci 34:10950-10962. CrossRef Medline

Nimchinsky EA, Oberlander AM, Svoboda K (2001) Abnormal development of dendritic spines in FMR1 knock-out mice. J Neurosci 21: 5139-5146. Medline

Osterweil EK, Krueger DD, Reinhold K, Bear MF (2010) Hypersensitivity to mGluR5 and ERK1/2 leads to excessive protein synthesis in the hippocampus of a mouse model of fragile X syndrome. J Neurosci 30:1561615627. CrossRef Medline

Pacey LK, Doering LC (2007) Developmental expression of FMRP in the astrocyte lineage: implications for fragile X syndrome. Glia 55:1601-1609. CrossRef Medline

Pan F, Aldridge GM, Greenough WT, Gan WB (2010) Dendritic spine instability and insensitivity to modulation by sensory experience in a mouse model of fragile X syndrome. Proc Natl Acad Sci U S A 107:17768-17773. CrossRef Medline

Peterson RT, Schreiber SL (1998) Translation control: connecting mitogens and the ribosome. Curr Biol 8:R248-R250. CrossRef Medline

Qin M, Kang J, Burlin TV, Jiang C, Smith CB (2005) Postadolescent changes in regional cerebral protein synthesis: an in vivo study in the FMR1 null mouse. J Neurosci 25:5087-5095. CrossRef Medline

Qin M, Schmidt KC, Zametkin AJ, Bishu S, Horowitz LM, Burlin TV, Xia Z, Huang T, Quezado ZM, Smith CB (2013) Altered cerebral protein synthesis in fragile $\mathrm{X}$ syndrome: studies in human subjects and knockout mice. J Cereb Blood Flow Metab 33:499-507. CrossRef Medline

Regan MR, Huang YH, Kim YS, Dykes-Hoberg MI, Jin L, Watkins AM, Bergles DE, Rothstein JD (2007) Variations in promoter activity reveal a differential expression and physiology of glutamate transporters by glia in the developing and mature CNS. J Neurosci 27:6607-6619. CrossRef Medline

Robinson MB, Hunter-Ensor M, Sinor J (1991) Pharmacologically distinct sodium-dependent $\mathrm{L}-[3 \mathrm{H}]$ glutamate transport processes in rat brain. Brain Res 544:196-202. CrossRef Medline

Rothstein JD, Patel S, Regan MR, Haenggeli C, Huang YH, Bergles DE, Jin L, Dykes Hoberg M, Vidensky S, Chung DS, Toan SV, Bruijn LI, Su ZZ, Gupta P, Fisher PB (2005) Beta-lactam antibiotics offer neuroprotection by increasing glutamate transporter expression. Nature 433:73-77. CrossRef Medline

Roux PP, Shahbazian D, Vu H, Holz MK, Cohen MS, Taunton J, Sonenberg N, Blenis J (2007) RAS/ERK signaling promotes site-specific ribosomal protein S6 phosphorylation via RSK and stimulates cap-dependent translation. J Biol Chem 282:14056-14064. CrossRef Medline

Rudelli RD, Brown WT, Wisniewski K, Jenkins EC, Laure-Kamionowska M, Connell F, Wisniewski HM (1985) Adult fragile X syndrome. Cliniconeuropathologic findings. Acta Neuropathol 67:289-295. CrossRef Medline

Sharma A, Hoeffer CA, Takayasu Y, Miyawaki T, McBride SM, Klann E, Zukin RS (2010) Dysregulation of mTOR signaling in fragile X syndrome. J Neurosci 30:694-702. CrossRef Medline 
Takasaki C, Okada R, Mitani A, Fukaya M, Yamasaki M, Fujihara Y, Shirakawa T, Tanaka K, Watanabe M (2008) Glutamate transporters regulate lesion-induced plasticity in the developing somatosensory cortex. J Neurosci 28:4995-5006. CrossRef Medline

Tanaka K, Watase K, Manabe T, Yamada K, Watanabe M, Takahashi K, Iwama H, Nishikawa T, Ichihara N, Kikuchi T, Okuyama S, Kawashima N, Hori S, Takimoto M, Wada K (1997) Epilepsy and exacerbation of brain injury in mice lacking glutamate transporter GLT-1. Science 276: 1699-1702. CrossRef Medline

Till SM, Asiminas A, Jackson AD, Katsanevaki D, Barnes SA, Osterweil EK, Bear MF, Chattarji S, Wood ER, Wyllie DJ, Kind PC (2015) Conserved hippocampal cellular pathophysiology but distinct behavioural deficits in a new rat model of FXS. Hum Mol Genet 24:5977-5984. CrossRef Medline

Yang Q, Feng B, Zhang K, Guo YY, Liu SB, Wu YM, Li XQ, Zhao MG (2012) Excessive astrocyte-derived neurotrophin-3 contributes to the abnormal neuronal dendritic development in a mouse model of fragile $\mathrm{X}$ syndrome. PLoS Genet 8:e1003172. CrossRef Medline

Yang Y, Gozen O, Vidensky S, Robinson MB, Rothstein JD (2010) Epigenetic regulation of neuron-dependent induction of astroglial synaptic protein GLT1. Glia 58:277-286. CrossRef Medline

Yang Y, Vidensky S, Jin L, Jie C, Lorenzini I, Frankl M, Rothstein JD (2011) Molecular comparison of GLT1 + and ALDH1L1+ astrocytes in vivo in astroglial reporter mice. Glia 59:200-207. CrossRef Medline 